\title{
Inscriptions of Early Āndhradeśa: Results of fieldwork in January and February 2016
}

\author{
Stefan Baums, Arlo Griffiths, Ingo Strauch and Vincent Tournier ${ }^{*}$
}

This is the accepted version of a forthcoming article in Bulletin de l'École Française d'Extrême-Orient 102:

http://www.efeo.fr/base.php?code=643

Accepted version downloaded from SOAS Research Online: http://eprints.soas.ac.uk/23279/

[Please do not quote or circulate without permission from the authors]

\section{Introduction}

From 2015 through 2017, the EFEO is administering an international collaborative research project entitled "From Vijayapurī to Śrīksetra: the beginnings of Buddhist exchange across the Bay of Bengal." This project aims to investigate the early phases of Buddhist exchange across the Bay of Bengal based on a comprehensive study of the epigraphic record of the site of Nagarjunakonda (on the border of Telangana and Andhra Pradesh states) in India, and Śrikșetra (near the modern town of Pyay) in Myanmar, as well as related sites in both countries. ${ }^{1}$ It will in due course deliver publications of the two epigraphic corpora in question, as a basis for comprehensive interdisciplinary investigation of the early history of Buddhist exchange between the east coast of India and the Pyu civilization of the Irrawady river valley in Burma.

As members of this larger project, we recently undertook fieldwork in the states of Telangana and Andhra Pradesh-an area we shall henceforward refer to as Āndhradeśa - with the principal aim to document inscriptions dating from the Ikșvāku period $\left(3^{\text {rd }}-4^{\text {th }}\right.$ centuries $\left.\mathrm{CE}\right)$. We recorded the present locations of known inscriptions as well as recent discoveries and took photographs, as a first step towards the publication of a corpus of the inscriptions of this period. Rather than concentrating only on the principal Ikșvāku site (Nagarjunakonda) and the few other sites that have yielded inscriptions in the same characteristic Ikssvāku script (Jaggayyapeta, Ghantasala, Phanigiri), we decided soon after our arrival in the field to cast our net more widely and to document all epigraphic material relevant to the early epigraphy of Āndhradeśa. Our reasons for doing so were that most of the sites immediately relevant for the aforementioned project have also yielded older inscriptions (mainly of the Sātavāhana period); that Buddhist inscriptions become rare in the area after the Ikssvāku period, while there is reason to believe the most intensive period of epigraphical production in the Pyu context started only after that period (perhaps in the $5^{\text {th }}-7^{\text {th }}$ c. range); and that explicitly non-Buddhist inscriptions are rare in Āndhradeśa before the rise of the Câlukya dynasty in the $7^{\text {th }}$ century. The Indian wing of our project has thus evolved into a comprehensive survey of the Early

\footnotetext{
* The authors are affiliated respectively with the Ludwig-Maximilians-Universität München; the EFEO and UMR 5189, Histoire et sources des mondes antiques, Université de Lyon; the Université de Lausanne; and SOAS, University of London. They express their gratitude, for help received in connection with the research reported on in these pages, to Peter Bisschop, Emmanuel Francis, Valérie Gillet, Akira Shimada, and Jonathan Silk.

${ }^{1}$ The project is funded from 2015 to 2017 by a grant from the R.N. Ho Family Foundation program in Buddhist Studies, administered by the American Council of Learned Societies.
} 
Inscriptions of Āndhradeśa (EIAD), covering all records from the beginning of the epigraphic tradition in this part of India up to the rise of Telugu as epigraphical language of expression in the second half of the first millennium, as rough chronological cut-off point. ${ }^{2}$

No previous listing of the early epigraphy of Āndhradeśa, thus defined, exists, because previous research has tended to focus exclusively on the Ikșvāku corpus, or exclusively on Buddhist material. Thus, the booklet Inscriptions of the Ikshvāku Period by Srinivasan \& Sankaranarayanan (1979) contains metadata on (but not the actual texts of) seventy-six inscriptions of the Ikșvāku period plus four inscriptions of the Ābhīras. The inscriptions are arranged chronologically to the extent possible, and the work is on the whole well done, but does not seem to have included a solid fieldwork component, so that most entries are said to be "now kept in the Museum," i.e., the Museum of the Archaeological Survey of India (ASI) at Nagarjunakonda, whereas this Museum's records, dating back well before 1979, lack corresponding entries for quite a few. ${ }^{3}$ Raghunath's book The Ikșvākus of Vijayapuri (2001) presents itself as a comprehensive corpus for the Ikșvāku period. The work is however poorly done to the point of being unusable. ${ }^{4}$ Neither of these two works defines precisely on what grounds certain inscriptions which do not mention any Ikșvāku monarch are nevertheless included in their listings, while apparently absence of such mention is in general the reason for not including others.

Two other works are not focused on the Ikșvāku period, but on Buddhist inscriptions, which means excluding the-admittedly rare-non-Buddhist epigraphy of early Āndhradeśa. The book entitled Buddhist Inscriptions of Andhradesa, brought out by Hanumantha Rao et al. in 1998, covers a large percentage of the Buddhist inscriptions of Ândhradeśa, presenting stone inscriptions from more than thirty-five

2 See Nagaraju (1995: 10): "The new phenomenon emerges not in the then agriculturally rich, politically well-consolidated, and culturally forward regions of the Krishna and Godavari valleys, but in the far southern region of Andhra, in Rayalaseema to the south and west of the Nallamalai hills. The earliest Telugu inscriptions datable to the sixth century C.E. come from the district of Cuddapah. From the seventh century Telugu inscriptions begin to appear in the adjoining districts of Anantapur, Chittoor, Nellore and Prakasam, and in the western dry belt of Guntur. In the next century (the eighth), the use of Telugu in epigraphical records is seen farther to the north in the districts of Mahaboobnagar and Nalgonda. Except for one doubtful record, the early Telugu inscriptions in Krishna district are datable to the ninth century. The first Telugu inscription in Warangal district belongs to the late ninth or early tenth century C.E. All other districts of northern Andhra (Karimnagar, West and East Godavari, Visakhapatnam, Vijayanagaram, and Srikakulam) open their accounts only in the eleventh century C.E."

${ }^{3}$ Their inscription no. 71 (EIAD 77), for instance, on a broken pillar found at the site called "University," was said to be "kept in the Museum," although it is today found in the reconstructed site at Anupu on the South shore of the Nagarjuna Sagar, and presumably never entered the Museum; for none of the Jaggayyapeta pillar inscriptions (their nos. 22-24, EIAD 31-33) is any indication of their whereabouts made, whereas at least one of them has apparently been kept in the Government Museum at Madras/Chennai since 1901 (acc. no. 1901/72); their no. 75 (EIAD 99) is not engraved on a "white marble slab" but on the flank of a sculpture of a lion.

${ }^{4}$ Among many issues, let us mention here only the fact that the work contains multiple entries for single inscriptions. Its 7A, for instance, is the same inscription as its 9B (EIAD 9); its $10 \mathrm{~B}=10 \mathrm{D}$ (EIAD 17); its 13D = 24 (EIAD 27); etc.). Its usefulness is further impaired by an astounding number of misprints. 
sites in addition to all copper-plate inscriptions of Āndhradeśa that involved grants to Buddhist institutions. Nevertheless, it is not free of omissions in terms of sites, ${ }^{5}$ and like the other works mentioned here was compiled without systematic collection of material in the field, so that listings for included sites are also not exhaustive. ${ }^{6}$

The same objection must be raised, even more forcefully, against the relevant volume of A Comprehensive Study of the Indian Buddhist Inscriptions (Tsukamoto 1996, 1998). ${ }^{7}$ This work was obviously not based on any fieldwork component at all, and its literature review shows surprising omissions: Rentala, site of a Buddhist inscription of the Ikșvāku period whose discovery goes back to 1936-37, is missing; ${ }^{8}$ so is the Palnad Marble of the post-Ikșvāku period; ${ }^{9}$ not to mention the numerous copper-plate inscriptions recording donations to Buddhist institutions or the potsherd inscriptions from Salihundam. ${ }^{10}$ The work covers only a meager seventeen sites for "Southern India," i.e., Tamil Nadu and undivided Andhra Pradesh, and is incomplete even for the sites that it does cover. We are thus, at least for this part of Tsukamoto's work, unable to agree with the high praise accorded to it by Gérard Fussman when he reviewed the work in the pages of this Bulletin fifteen years ago. ${ }^{11}$ But the French scholar was very right to remind his readers of the state of the art:

The scholarly backwardness of epigraphy as it is practiced in India today has often been lamented by our Indian colleagues themselves. Tens of thousands of inscriptions remain unedited, those which are published are not published well and since a number of years even less well printed. Errors of reading and

\footnotetext{
${ }^{5}$ For instance, it does not record Raghunath's 58A (EIAD 78), a pre-Ikṣvāku Buddhist inscription from Gangaperuru: reported first in ARIE 1939-40, B.17, p. 228 and reported again by Parabrahma Sastry (1975, no. 366), this inscription was first published by Srinivasan (1965) and republished by Parabrahma Sastry (1977: 1, no. 1).

${ }^{6}$ Thus for instance only four entries are included for the site Ghantasala (see below), whereas our inventory lists eleven inscriptions for this site.

${ }^{7}$ Shizutani 1965 is an earlier Japanese compilation of Buddhist inscriptions from Āndhradeśa on which Tsukamoto drew.

${ }^{8}$ EIAD 2. See ARIE 1936-37, B.349, p. 62; Sankaranarayanan 1967-68: 31-32; Raghunath 2001: 69 (no. 2). The present whereabouts of this inscription are unknown to us.

${ }^{9}$ EIAD 138. See Sewell 1880: 63-66; British Museum, acc. no. 1880,0709.67.

${ }^{10}$ For copper-plate grants to Buddhist institutions that could have been known to Tsukamoto, see Sankaranarayanan 1977 (items I, VIII, XI and XII); on the Buddhist epigraphic material from Salihundam, see Gadre 1955-56 and Khan 1969. For all of these, see Hanumantha Rao et al. 1998, itself obviously a source that appeared too late for it to be taken into account by the compilers of $A$ Comprehensive Study of the Indian Buddhist Inscriptions. Inexplicable omissions of this kind are so numerous in this work that we consulted our colleague Akira Shimada asking whether Tsukamoto's Japanese-language Introduction explains his criteria for inclusion or exclusion of certain inscriptions. In an email of 31/03/2016, Shimada answered: "[Tsukamoto's Preface and Introduction] do not explain the collection policy (date, medium etc.). I do not think Tsukamoto intended to collect only stone inscriptions, as the volume includes copper plate inscriptions and inscriptions cut on bronze images, particularly in the Eastern India section. I guess he and his team simply did not know many Salihundam, Vaddamanu and copper-plate inscriptions found in Andhra, as they did not have good access to resources."

${ }^{11}$ G. Fussman, review in BEFEO 88 (2001), pp. 383-385. See p. 383: «L'ouvrage est monumental, la conception grandiose, la réalisation parfaite » (our emphasis).
} 
of printing are so numerous that it is never possible to rely on a publication. It is always necessary to consult the original, which is rarely reproduced in usable form. Comprehensive tools that would allow the historian to use this enormous quantity of material are lacking. ${ }^{12}$

Progress in the field of Indian epigraphy must be based not only on a comprehensive survey, but first-hand reading and re-reading of inscriptions, which in turn require access to publications as well as to usable reproductions. In the absence of the latter, it is generally necessary to go and find the original inscriptions in the sites or museums where they are preserved. Given this state of affairs, the task we have defined for ourselves is in the first instance to compile an exhaustive inventory of the early epigraphy of Āndhradeśa, without any limitations in terms of religion or dynasty, an inventory that assembles the most important metadata concerning each inscription-its find-spot, present place of preservation, available estampages or photos, relevant bibliography, but also the nature (object type) of the support on which it is engraved, its dimensions, the number of lines that it spans, and the language(s) in which it is formulated. We will publish our inventory and discuss its features in greater detail in a future publication, but already begin here to make use of the fixed EIAD numbers that we assign to the inscriptions. ${ }^{13}$

In what follows, we first present a narrative account of our two weeks of fieldwork in January and February 2016, and then illustrate the results of our work so far by discussing in detail a selection of specific inscriptions, several of them so far unpublished, from three different sites. ${ }^{14}$ A map (fig. 1) shows the principal places mentioned in this report.

Fieldwork in January and February 2016

Project coordinator Arlo Griffiths spent 25-29 January in Delhi to obtain authorization for work at Nagarjunakonda from the headquarters of the Archaeological Survey of India (ASI). Much of the preparatory work having been accomplished through email exchange with the ASI's Director of Museums

\footnotetext{
${ }^{12}$ Ibid. : «Le retard scientifique de l'épigraphie telle qu'on la pratique aujourd'hui en Inde a souvent été dénoncé par nos collègues indiens eux-mêmes. Des dizaines de milliers d'inscriptions restent inédites, celles que l'on publie sont mal publiées et depuis quelques années plus mal imprimées encore. Les erreurs de lecture et d'impression sont si nombreuses qu'on ne peut jamais faire confiance à la publication, il faut toujours se reporter à l'original, rarement reproduit sous forme utilisable. Les instruments de synthèse qui permettraient à l'historien d'utiliser cet énorme matériel font défaut. »

${ }^{13} \mathrm{We}$ intend to publish our inventory, editions and translations on the website http://epigraphia.efeo.fr/andhra.

${ }^{14}$ Our transliteration system is compliant with ISO standard 15919 (see the entry ISO 15919 in our bibliography), except for our consistent use of the raised circle ${ }^{\circ}$ to indicate independent vowel signs, rather than the colon sign : prescribed by ISO 15919, rule 15, only when it is necessary to disambiguate transliterations. Our editorial conventions are as follows: we give physical line numbers in parentheses and bold face; square brackets [ ] surround uncertain readings; parentheses ( ) editorial restorations of lost text; angle brackets \langle\rangle editorial additions of omitted text; question marks represent entirely illegible akșaras; the plus sign akșaras that are entirely lost; the diamond symbol $\diamond$ horizontal space used as punctuation; triple slash /// the left or right edge of the support if it is fragmentary.
} 
Dr. Urmila Sant, the process did not meet with any obstacles. During his short stay in New Delhi, Griffiths had the opportunity to visit the National Museum, which is home to a Nagarjunakonda inscription published by Dutch archaeologist J.Ph. Vogel, engraved on the buddhapāda excavated by his British colleague A.H. Longhurst in the 1920s (acc. no. 50.24). ${ }^{15}$

All authors of this report then assembled in Hyderadad on Saturday the $30^{\text {th }}$ of January. The next day, we paid a first informal visit to the Telangana State Museum, whose collections apparently comprise all those of the State Museum of former undivided Andhra Pradesh. It is home to two fragments of inscriptions excavated at Phanigiri: ${ }^{16}$ for more on inscriptions from this site, which falls within what is now Telangana, see below. We also observed that two so-called drum slabs from Chandavaram (a site which falls within the new state of Andhra Pradesh) bear inscriptions: the one with mason's marks 108 , the other with an all but illegible inscription in two lines. ${ }^{17}$

On the morning of Monday the $1^{\text {st }}$ February, we went to meet the director of the Telangana State Department of Archaeology and Museums, Mrs. N.R. Visalatchi, in order to discuss our work and seek her advice. Among Buddhist sites in Telangana State, we were previously aware of inscriptions having been found at Phanigiri, so planning a visit to that site was our main subject of discussion. Phone calls were made for this visit to take place on the $3^{\text {rd }}$. Next we visited the Telangana State Archaeological Museum, which is home to further fragments of Phanigiri inscriptions. ${ }^{18}$ Unfortunately they are kept in a glass case, and despite repeated efforts it turned out to be impossible to locate the keys that would have made it possible to open the case in order take good photographs of these fragments. In the afternoon, we went to the office of the Hyderabad Circle of the ASI, in order to meet Superintending Archaeologist Nizamuddin Taher. His staff members Asst. Superintending Archaeologist Ch. Babji Rao and Dy. Superintending Archaeologist D. Kanna Babu also attended the meeting. We discussed various sites to be visited in both states that fall under the Hyderabad Circle's jurisdiction.

Tuesday the $2^{\text {nd }}$ was an election day, so site or museum visits were impossible. We were joined in the evening by Valérie Gillet of the Pondicherry EFEO center, who was to accompany us during the next ten days. Wednesday $3^{\text {rd }}$ February, we drove out early in the morning in the direction of Phanigiri. In the village, we were awaited by archaeologist Rajulu. We first visited the site which lies on top of the hill that has given the village its name. One inscription, previously unpublished, remains on the site: it is engraved on a pillar which stands on the

\footnotetext{
${ }^{15}$ EIAD 96. See Vogel 1929-30b; Longhurst 1938: 24, pl. XIXa; Raghunath 2001: 191 (no. 77).

${ }^{16}$ EIAD 112 (acc. no. 2005-401, unpublished) and 113 (acc. no. 2005-402, Subrahmanyam et al. 2008: 37, no. 9).

${ }^{17}$ EIAD 237 (acc. no. 6651) and 238 (acc. no. 229). The only published epigraphic material from Chandavaram that we are aware of are the two short inscriptions presented by Hanumantha Rao et al. 1998: 123. It appears that neither one of these can be identified with anything we saw at the Museum.

${ }^{18}$ EIAD 116 (Subrahmanyam et al. 2008: 36, no. 6), 117 (unpublished) and 118 (unpublished). No acc. nos. seem to have been assigned to these fragments.
} 
western a ayaka platform of the heavily restored mahācaitya. ${ }^{19}$ The astoundingly beautiful statues, torana and other artwork from the site are stored in a house in the village, along with a small handful of significant inscriptions, which we were able to document. For more details on Phanigiri and its inscriptions, see below (pp. 12-19).

On the $4^{\text {th }}$ of February, we returned to the Telangana State Museum in order to document the two Phanigiri fragments identified on $31^{\text {st }}$ of January as well as some of the important copper-plate inscriptions held in this Museum's rich collection, among them most notably the only Ikșvāku copper-plate grant known to date: the Patagandigudem charter of Ehavala Cāntamūla. ${ }^{20}$ We were also able to photograph interesting grants to Buddhist institutions of the Viṣnukuṇin period. ${ }^{21}$ In the evening we drove to our next base, at Vijayawada.

From here, on Friday the $5^{\text {th }}$ of February, we visited Guntupalli in West Godavari District, the site furthest to the northeast that we were able to visit during our trip. Its interesting epigraphic corpus does not comprise any Ikșvāku inscription as such: it mainly comprises inscriptions that may be assigned to the Sātavāhana period, but also includes an inscription of Śālankāyana Nandivarman as well as a citation inscription in a script that seems posterior to the Ikșvāku period. ${ }^{22}$ The disconcerting conclusion of our visit was that almost none of the interesting inscriptions brought to light in the 1970s, some of which were still present on the site in the early $1980 \mathrm{~s},{ }^{23}$ can be found here today. Enquiries made with ASI officers in Hyderabad on where the missing inscriptions might have been moved did not yield any answers. By way of compensation, however, we were able to track down a recently discovered and still unpublished inscription, which we present in more detail below (pp. 8-11).

The next day, Friday the $6^{\text {th }}$ of February, we visited the site Ghantasala (ancient Kantakasola, known to Ptolemy as Kantakossyla), ${ }^{24}$ whose epigraphic corpus was published by J.Ph. Vogel in 1947-48. Vogel knew a total of five inscriptions from this site, including a set of two pillars as well as a sculpture of a lion engraved in the script characteristic of the Iksvāku corpus-although no king of any dynasty is mentioned here-and all these three inscriptions are safely preserved in the site museum. ${ }^{25}$ The other two inscriptions published by Vogel, in somewhat more archaic script, could unfortunately not be traced. ${ }^{26} \mathrm{We}$ did, on the other hand, find an inscribed colonette that had been discovered after Vogel's publication, ${ }^{27}$ as well as a handful of seemingly unpublished items. In this connection, we must mention an article by Somasekhara Sarma (1974). Although it does not mention

\footnotetext{
${ }^{19}$ EIAD 114.

${ }^{20}$ EIAD 55; acc. no. 98-15. See Falk 1999-2000.

${ }^{21}$ On some of these, see Tournier in progress.

${ }^{22}$ See Sircar 1969-70 (no. 1), Sankaranarayanan 1977-78, Sarma 1988 (chapter 3), and Skilling 1991.

${ }^{23}$ We know this from photographs that John Huntington was able to take during a visit in that period, and which this colleague has kindly shared with us.

${ }^{24}$ See Ghosh 2006.

25 EIAD 97-99; Vogel 1947-48, items A, B and C. The first bears museum no. 27, the second and third stones did not show any number.

${ }^{26}$ EIAD 100 and 124; Vogel 1947-48, items D and E.

${ }^{27}$ EIAD 126; ARIE 1956-57, B.41; museum no. 2.
} 
Vogel's previous publication, it nevertheless seems to be based on it for readings and estampages. The author claims to have visited the site, but presents almost no new information based on field observations except for the following (Sarma 1974: 2):

I was told that the foundations of some stüpas were found in some places when excavations were made by private people and that some inscriptions were discovered on the foundation slabs and stones of the stüpa. I have seen some years back printed copies of these inscriptions with a friend of mine who wanted to publish them in a Telugu journal. Unfortunately he has not published them until now and I do not know if the blocks prepared out of the estampages of those inscriptions are now extant, and if that friend preserved even those estampages. The letters are in the shape of floral designs and exactly resemble those of the inscriptions of the island of Jāva which were edited by the late K.P. Jayaswal in the Epigraphia Indica Vol. XXII p. $4 \mathrm{ff}$.

This is clearly a reference to the presence of śankhalipi at Ghantasala, and among the apparently unpublished material that we found was indeed one slab with an inscription in this script (fig. 2), around the short label inscription sumanaśila in Late Southern Brāhmī of about the $6^{\text {th }}$ or $7^{\text {th }}$ century (fig. 3). ${ }^{28}$ Another label inscription from roughly the same period reads $\|n \bar{a} g \bar{a} r j u n a s i r i ̄\|($ fig. 4$) .{ }^{29}$

On Saturday the $7^{\text {th }}$ February we drove from Vijayawada to Nagarjunakonda through Guntur and Amaravati. At Guntur, we visited the Bauddhasri Archaeological Museum where, thanks to the very helpful officer in charge, Mr. R. Phalguna Rao, we were able to document a set of three copper-plate inscriptions of the $6^{\text {th }}$ century, found at the site Kondavidu, that cast interesting light on the post-Ikșvāku history of Buddhism in this region and have not yet been served by a good publication. ${ }^{30}$ At Amaravati, we first stopped by the Archaeological Museum and Interpretation Centre "Kalachakra," not knowing that a rather rich collection of Sātavāhana-period inscriptions awaited us here. This collection assembles materials from various early sites of undivided Andhra Pradesh, notably Kesanapalli whose epigraphical corpus is the only one of these sites to have been prominently published..$^{31}$ Next, we visited the main archaeological site and the site museum, but as we had neglected, at the ASI headquarters in New Delhi, to request authorization for photography at the Amaravati site museum, we were unable to do more than note the inscriptions preserved there, and had to postpone this task until a future visit. We arrived late at night at our hotel on the northern shore of Nagarjunasagar.

On February $8^{\text {th }}$ through $11^{\text {th }}$ we were able to work on Nagarjunakonda island under the very helpful supervision of ASI officer G. Surya Prakash. In the present state of our knowledge, Nagarjunakonda inscriptions are stored at various separate

${ }^{28}$ EIAD $128 \mathrm{~A}$ and B; the stone bears no museum number.

${ }^{29}$ EIAD 125; the stone bears no museum number.

${ }^{30}$ EIAD 187-189; Bauddhasri Archaeological Museum acc. nos. 171, 170, 169; see Krishna Sastry 1990 and Hanumantha Rao et al. 1998: 211-219.

${ }^{31}$ See Khan 1969. Several of the inscriptions from other sites held in this museum do figure in Hanumantha Rao et al. 1998. 
locations: one, as mentioned above, is held at the National Museum in New Delhi. On the island itself, several inscriptions are prominently exhibited in the Nagarjunakonda Museum, while some minor or fragmentary items are kept in one or the other of two storage spaces inside this museum that are not normally open to the public. There is a separate storage shed, also not normally open to the public, situated along the path to the reconstructed Great Caitya; at the latter, two fragments of inscriptions are mounted respectively on the western and southern ayaka platforms; and, finally, on the way to the storage shed there is an enclosure inside a medieval fortification, the gate into which has been filled up with stones, but which can be reached by clambering over the walls. Most of these locations shelter more than one inscription, and not all of these bear ASI inventory numbers. On the southern shore of Nagarjuna Sagar, in the village Anupu, one more inscription is to be found in the so-called University site. All these locations combined, we have identified a total of 66 Nagarjunakonda inscriptions, among which 8 are previously unpublished. However, there is also a substantial number of inscriptions that in all probability were never moved away from Nagarjunakonda but that we have not yet been able to trace. Some of these may still be identified during future fieldwork, as we did not have time to turn all stones at all the locations on the island. One inscription we were able to identify on the island is the subject of detailed discussion below (pp. 19-26).

On $12^{\text {th }}$ February we drove back to Hyderabad. Before our team parted ways, we had occasion to visit the Birla Science Museum, which holds numerous inscribed artifacts-potsherds as well as stone architectural elements-from the site Vaddamanu, which was the subject of private excavations in the 1980s and received an excellent excavation report. ${ }^{32}$ In this report, and at the Museum, the site is considered to be Jaina, but sound arguments for assuming this religious affiliation seem to be lacking, and we assume that the epigraphic material from Vaddamanu is part of the history of Buddhism.

\section{Limestone mandapa pillar from Kantamanenivarigudem, near Guntupalli}

The group of Buddhist monuments at Guntupalli is situated on a horseshoe-shaped hill at about $40 \mathrm{~km}$ north of Eluru, headquarters of West Godavari District in Andhra Pradesh, and $10 \mathrm{~km}$ west of the mandal headquarters Kamavarapukota. The site comprises, among other remains, a rock cut caitya shrine and rock-cut monastic quarters, as well as stüpas constructed in brick. The group has been the object of repeated archaeological investigations from the $19^{\text {th }}$ century onward ${ }^{33}$ and has yielded a number of inscriptions. ${ }^{34}$ Already in 1976, the ASI undertook explorations at a site near the village Kantamanenivarigudem or Jeelakaragudem, $c a 2.5 \mathrm{~km}$ south of Guntupalli. ${ }^{35}$ In 2006, the ASI excavated the remains of two apsidal caitya halls.

\footnotetext{
${ }^{32}$ Sastri et al. 1992.

${ }^{33}$ See Shimada 2013 for an overview of scholarship to date.

${ }^{34}$ The inscriptions are presented in Sarma 1988, chapter 3. As we noted above, only few of these inscriptions can still be traced today.

${ }^{35}$ See IAR 1976-77, p. 10: "Shri I. K. Sarma of the South-eastern Circle of the Survey located an ancient site near Kantamanenivarigudem on the bank of an ancient nullah towards south-west of Guntupalli. The site was found studded with baked brick structures. The exposed sections of the site
} 
The results of these excavations have not yet been published. Some information was, however, made public in short newspaper articles. ${ }^{36}$ According to one of these, an inscribed pillar was found in the vicinity of a caitya. Based on a preliminary reading prepared by D. Kanna Babu, then Assistant Superintending Archaeologist of the ASI's Hyderabad Circle, the inscription would be translatable as follows: "Gift of vessel full of coins (Masakas) made to the benefit of Aryasangha and followers of Dakiniyana residing at Jinanagamahaparvatha by the householder (Nagaputa) hailing from Sakuda along with his wife Bodhi and daughter." During our visit to Guntupalli, local people showed us where the inscription has been discovered $\left(81^{\circ} 06^{\prime} 53.9 \mathrm{E}, 16^{\circ} 59^{\prime} 46.4 \mathrm{~N}\right)$ and subsequently made it possible for us to document this artifact in a storage building at the entrance of the site. Being rectangular in section, it may have to be classified as a pilaster; it is fragmentary, because both upper and lower extremity of the original have broken off. The fragment measures $108 \mathrm{~cm}$ in height, $40 \mathrm{~cm}$ in width, and $14 \mathrm{~cm}$ in thickness (fig. 5). Remains of a half octagonal section are visible on the top, developing down into the very common halflotus motif, below which is applied a band of animals (a lion, a goat or a horse, a pig/boar) moving along the pilaster in pradaksina. ${ }^{37}$ These ornamental elements are also continued on the two lateral faces (fig. 6). On the large flat surface that makes up the lower part of the front face is found an inscription in three lines covering almost the entire width of this face, the inscribed surface measuring $12 \mathrm{~cm}$ in height (fig. 7). We have assigned it the inventory number EIAD 220. Our reading and translation are presented below.

EIAD 220

(1) sakule gahapatino nāg[u]tarasa bharayāya b[odhā]-

(2) ya saduhutukāya dānam mahānāgapavate ${ }^{\circ}$ ari[ya]-

(3) sa[gha]sa savadakhiniyānam samo[sa]rane ${ }^{38}$

"(This is) the gift of Bodhā, wife of the householder Nāgutara (Skt. Nāgottara) in Sakula, together with (her) daughter(s), at the gathering hall of those worthy of all honor of the noble community at Mahānāgapavata."

The first part of the text poses no particular problems and is largely parallel to a previously published epigraph on a limestone pillar from Guntupalli. ${ }^{39}$ According to

revealed a cultural sequence extending from the early historical to the late medieval times. Among the finds, mention may be made of a sculpture of Jaina tirthankara and sherds of black-and-red and redslipped wares."

${ }^{36}$ See http://www.thehindu.com/todays-paper/tp-national/tp-andhrapradesh/buddhist-chaitya-gruhasdiscovered-in-west-godavari/article1871700.ece and http://www.thehindu.com/todays-paper/tpnational/signs-of-early-dakiniyana-buddhism/article3092455.ece (both accessed $25^{\text {th }}$ July 2016).

${ }^{37}$ For a comparable pillar, but one that is square in section, see Rosen Stone 1994: 81 and fig. 240.

${ }^{38}$ In 1.1 -patino, the shape of no is irregular. In 1.2 dannam, the shape of $d \bar{a}$ is irregular.

${ }^{39}$ Our EIAD 216. See Srinivasan 1973: 250-251 (II), pl. II; Sarma 1978: 54-55, pl. VIII-10; Sarma 1988: 65-66, 77-78 (I-14, misprint for I-10), pl. 29 (A, B, C). A long inscription of Śālankāyana Nandivarman (our EIAD 164) was added below EIAD 216 several centuries after it had been initially 
our revised reading based on the published images of this pillar, this inscription contains the following text:

EIAD 216

(1) sa[ku]le gahapatat[i]no hamghasa

(2) bhariyāya ${ }^{\circ}$ upāsikāya budh[i]-

(3) ya deyadhama ${ }^{\circ}$ inammi mahā-

(4) selamaḍave jasakhambhā

(5) māhā[n]āgapavate ${ }^{\circ}$ ariyasaṁ-

(6) ghasa patith $[\bar{a}] \operatorname{pitam}^{40}$

"The fame-pillar was established in this great stone pavilion as meritorious gift of the lay-follower Budhi, the wife of the householder Hangha in Sakula, for the noble community at Mahānāgapavata."

As we see, both epigraphs record donations by the wives of householders residing at a place named Sakula. This toponym can perhaps be associated with a place mentioned in the Cullahamsajātaka and situated near a Lake Manusiya. In this story, ${ }^{41}$ a king named Sakula is said to have ruled in the city after which he was named. The story is situated in the Mahimsaka country, a region that is also mentioned in the early inscription of the Mahāmeghavāhana king Siri-Sada found in four copies at Guntupalli. ${ }^{42}$ In a brief contribution on the matter, D.C. Sircar has identified the Mahimsaka country with "the present Chanda District of Maharashtra" (actually called Chandrapur nowadays), "to the immediate north of the East Godavari District" in Andhra Pradesh. ${ }^{43}$

Both donations are for the benefit of the noble community (ariyasamgha, Skt. arryasaimgha) of Mahānāgapavata, a toponym that is well attested as the ancient designation of the Guntupalli monastic complex in several inscriptions from the site. Whereas EIAD 216 contains one of the usual formulaic phrases used for deyadhamma donations, our new text deviates from this conventional pattern. Its final phrase savadakhiniyānam samo[sa]rane is unattested so far in any inscriptions known to us. The Prakrit word samosarana corresponds to Pali samosarana (Skt. samavasarana) "coming together, meeting, union, junction" (PTSD s.v.). This meaning "meeting, coming together" is implied by the Pali Ațthakathās, for instance

engraved. The whereabouts of this important pillar are not known to us and was unknown also to all authorities with whom we made enquiries on the epigraphical material from Guntupalli.

${ }^{40}$ Variant readings in editions Srinivasan 1973 (Sr) and Sarma 1988 (Sa): sa[ku]le] Sr; sidham Sa • bhariyāya] $\mathrm{Sr} ;$ bhariyayā $\mathrm{Sa} \bullet$ budh[i]ya] budhāya $\mathrm{Sr}$; budha(dhi)ya $\mathrm{Sa} \bullet$ mahāselamaḍave] mahāselamedava $\mathrm{Sr}$; mahāsela maḍave $\mathrm{Sa} \bullet$ patiț $[\bar{a}]$ pitami $]$ patithapitam $\mathrm{Sr} \mathrm{Sa}$.

${ }^{41} \mathrm{Cf}$. Ja V $337.20 \mathrm{ff}$.

42 EIAD 203-206. See Subrahmanyam 1968, pl; Sircar 1969-70: 35-36, pl. IV; Srinivasan 1973: 247-250, pl. I; ARIE 1974-75, B.7; Sarma 1978: 49-51, pl. II-1; Sarma 1988: 65, 68-71 (I-1). We only found one of these four pillars on the site (EIAD 204). In the early 1980s, John Huntington still found three (see Huntington Archive 26901, 26904, 26910).

${ }^{43}$ Sircar 1972-73: 166-168. 
in Buddhaghosa's commentary on the expression brāhmanagāma "brahmin village," in the Anguttaranikāya: ${ }^{.4}$

brāhmaṇagāmo ti brāhmaṇānam samosaraṇagāmo pi brāhmaṇagāmo ti vuccati brāhmaṇānam bhogagāmo pi

"brāhmanagāma: both a village that is a meeting place of brahmins and a village [the revenue of] which is enjoyed by brahmins are called 'brahmin village.",

This meaning is also attested in Buddhist Sanskrit texts, such as the Gandavyūha, where we find samavasarana embedded in a string of closely related terms, including samāgamana, saminipāta, upasamkramana. ${ }^{45}$ Speaking of the cognitive limitations of mahāśrāvakas such as Śāriputra, the text says:

nāpi tam acintyam bodhisattvavișayam bodhisattvasamāgamam bodhisattvasamavasaranamam bodhisattvasaminipātam bodhisattvopasamkramanam bodhisattvavikurvitam bodhisattvaprātihāryam bodhisattvaparșanmaṇ̦alam bodhisattvadigavasthānam bodhisattvasimhāsanavyūham bodhisattvabhavanam bodhisattvavihāram ... adrākṣuh |

"Also, they did not see the inconceivable range of Bodhisattvas, the coming together of Bodhisattvas, the gathering of Bodhisattvas, the approach of Bodhisattvas, the wonders of Bodhisattvas, the miracles of Bodhisattvas, the circle of the assembly of Bodhisattvas, the abiding by Bodhisattvas in the [various] directions, the magnificent array of the lion's seats of Bodhisattvas, the mansion of Bodhisattvas, the dwelling of Bodhisattvas."

Interestingly, the term samosarana is also well-known in Jaina sources, where it refers primarily to a sacred assembly held outdoors, before developing into a complex structure hosting such an assembly that is invested with highly elaborate symbolism. ${ }^{46}$ While in the Buddhist context, the use of samosarana/samavasarana to refer - by metonymy - to a place of religious assembly is, as far as we are aware, unattested, it is tempting to interpret this term in such a way in the Kantamanenivarigudem inscription. Indeed, as shown by EIAD 216 and by two other inscriptions from Guntupalli, ${ }^{47}$ there is a clear tendency for inscriptions engraved on pillars to refer-in the locative- to the broader structure to which they belong. Since the newly published pilaster is typologically similar to the mandapa pillars from the site-although it has the particularity of being cut in half-one might speculate that it could have belonged to a structure resembling a mandapa, but designated as samosarana.

The preceding term savadakhiniyānam was interpreted by Kanna Babu as reference to a hitherto unattested Buddhist school, the "Dakiniyana." It seems, however, preferable to interpret this word as a descriptive term for those assembled.

\footnotetext{
${ }^{44}$ Cf. AN-a II $285.27-28$ on AN I 180.15.

${ }^{45}$ Ed. Suzuki \& Idzumi 1949, pp. 17-18.

${ }^{46}$ For a rich survey of the meanings of this notion in Jaina literature, see Balbir 1994. On the use of samavasarana as a model for temple architecture in Medieval India, with a focus on Ellora, see Owen 2012: 15-39.

${ }^{47}$ Cf. Sarma 1988: 65-66, 75-76 (I-7, I-8), fig. 26-27 (EIAD 213-214).
} 
The only other attestation of the term known to us-albeit in its Sanskrit equivalent-is Śikșāsamuccaya (ed. Bendall 1897-1902) 286.4 śuśrūsanatā sarvadakșin̄yesu in a list of resolutions undertaken by a bodhisattva. Bendall \& Rouse (1902: 261) translate "readiness to hear for all those worthy of honour." We think, however, that this term in our inscription (and, by implication, also in the Sikșāsaтисcaya) should be interpreted in parallel with the epigraphic expression agrodaksinea "worthy of the highest honor" in line 8 of the Gāndhārī inscription of King Senavarman (CKI 249 in Baums \& Glass ongoing, line 8). The base word agadakșina in the Gāndhārī inscription of Śatrea (CKI 326, line 2) shows that here agra- modifies daksina $\bar{a}$ rather than daksininya, and by analogy savadakhiniya in our inscription should mean "worthy of all honor" (cf. also BHSD s.vv. daksininya, dakșineya).

\section{Two inscriptions from Phanigiri}

The Buddhist site of Phanigiri (Nalgonda Dt., Telangana), lies on the left bank of the Musi river, a tributary of the Krishna, approximately $90 \mathrm{~km}$ due east from Hyderabad, and about $130 \mathrm{~km}$ north from Nagarjunakonda. It forms part of a cluster of Buddhist sites also including Gazulabanda, Vardhamanukota, Thirumalagiri and Aravapalli. The site is located, just to the northeast of the village, on a hilltop shaped like a snake's hood that has given the site and village their name. First trial digs were carried out in 1941-44, and thorough excavations in four fieldwork seasons between 2001 and 2007. ${ }^{48}$ These brought to light a mahäcaitya with a diameter of $18 \mathrm{~m}$, seven smaller stūpas, two apsidal temples (cetiyaghara), congregation halls (mandapa) supported by pillars and six monastic living quarters (vihära), all dating from the $1^{\text {st }}$ century BCE to the $4^{\text {th }}$ century CE. The Great Caitya had four ayaka platforms in the cardinal directions. The western and northern platforms preserved several stumps of original sets of five lime-stone pillars each, and excavation of the congregation hall yielded a further 16 pillar stumps. Numerous pieces of lime-stone sculpture found at the great caitya, apsidal temples and congregation hall have attracted the attention of art historians for their rich content and beautiful execution and for their stylistic relationship to the Buddhist art of Amaravati and Nagarjunakonda. ${ }^{49}$

Phanigiri is also an important site for the early epigraphy of Āndhradeśa. According to Subrahmanyam et al. (2008: 32), "a total number of $42 \mathrm{Brahmi}$ inscriptions" were found there. ${ }^{50}$ So far, less than half of these ( 15 by our count) have been individually noted in the literature known to us, and not all of these with readings and illustrations. During our own fieldwork in February 2016, we located six Phanigiri inscriptions (EIAD 108, 111, 112, 114, 117 and 118) that to our knowledge have not been individually noted in the literature and that may or may not be included in the total number of 42 given by Subrahmanyam et al. 2008. We were

\footnotetext{
${ }^{48}$ Subrahmanyam et al. 2008: 5. See also the excavation reports for 2001-02 and 2002-03 available at http://museums.ap.nic.in/Phanigiri.html (accessed 11 June 2016).

${ }^{49}$ See for instance Skilling 2008.

${ }^{50}$ They go on to say that of these "nearly 40 are label inscriptions," but are clearly not using the term in the usual sense of an inscription labelling an element of narrative sculpture since they include in this number EIAD 104, to which we turn below.
} 
able to take good photographs of these six new inscriptions, and also to rephotograph 15 known Phanigiri inscriptions, which allowed us to re-evaluate and in several cases improve their previously published readings. In the following, we will as a sample present our improved reading and interpretation of a donative inscription, composed in Sanskrit and Prakrit, engraved on an octagonal pillar found on the ground near the staircase leading to apsidal temple I (EIAD 104), and introduce one of the new inscriptions (EIAD 114) located and read by us.

\section{EIAD 104}

The octagonal pillar bearing this inscription is kept in the ASI store house in Phanigiri village (fig. 8). Essentially intact, lacking only the original crowning element, it measures approximately $354 \mathrm{~cm}$ in height, with an inscribed area just above its base covering three of the pillar's eight facets in width and measuring $76 \mathrm{~cm}$ in height (fig. 9). ${ }^{51}$ It records the donation of a cakra (now lost, but presumably originally mounted on top of the pillar $)^{52}$ during the $18^{\text {th }}$ regnal year of the last known Ikṣvāku king Rudrapurușadatta. This is the latest known date of Rudrapurusadatta: previously Rudurapurusadatta's year 11, given in an inscription at Nagarjunakonda ${ }^{53}$ was considered the end of his reign, which by the discovery of the Phanigiri inscription is now extended a further seven years. The inscription has already been edited three times, and has already been frequently referred to in the literature..$^{54}$ This reflects this record's importance, not only for the chronology of the Ikșvāku kings, but also for the cultural history of Buddhism and for current Indological debates on the status of Sanskrit vis-à-vis vernacular languages. Indeed, the apologetic tone of the record, praising the Buddha for having destroyed the three poisons in a way that also stresses his superiority over both Śiva and Viṣnu/Krṣṇa, whose cults were favored by the Ikṣvāku kings, is quite remarkable, as noted by von Hinüber 2013b: 366-367. Such an apologetic stance is also clear from the very choice to include a versified portion in Sanskrit, a language that is used, in the Ikșvāku corpus, primarily for donations to non-Buddhist gods, while the business portion of this Buddhist record is in Prakrit. ${ }^{55}$ By appropriating the language of the other gods, so to speak, the Buddhist author of the Phanigiri poem skillfully positioned himself to attract the attention of those in power.

\footnotetext{
${ }^{51}$ This kind of pillar is rare at Ikṣvāku sites. For an example from Nagarjunakonda, see Rosen Stone 1994: 81, fig. 27.

${ }^{52} \mathrm{We}$ are not aware of any extant example of precisely such a pillar with wheel preserved, but depictions of such pillars are not too rare: see, from Phanigiri itself, the representation shown by Skilling 2008: 112 (fig. 25) and, from Nagarjunakonda, the depiction on a drum slab (Rosen Stone 1994, fig. 124); see also the relief at the entrance to the caitya at Karla, in Western Maharashtra, discussed by Bénisti 1961: 264-265 (fig. 2).

${ }^{53}$ EIAD 83. See Sircar \& Krishnan 1960-61: 20-22; Raghunath 2001: 182-184, no. 64.

${ }^{54}$ Munirathnam 2005, Ramesh \& Muniratnam 2011-12, Skilling \& von Hinüber 2011 (with a correction in von Hinüber 2013b: 366), Schneider 2014: 17-18 and Schneider 2015: 90, Hartmann 2015: 538 .

${ }^{55}$ For two exceptions to this pattern, dating from the later part of the Ikṣvāku rule in Nagarjunakonda, see Sircar 1963-64: 12-13, 17-18, nos. 4 \& 7.A (EIAD 54 \& 77).
} 
The exceptional nature of this record persuaded us to edit the inscription a fourth time when, upon close inspection of the original, it became clear that several improvements in the reading and interpretation could be offered. In what follows, we will begin by presenting our integral text and translation, and then discuss problematic passages and our solutions in line-by-line notes.

(1) siddham் $\|$ sam்vatsaram 108 hemamntapakṣam 3 divasam 3

prakkhyātadiptaya(2)śaso rājña śrīruddrapurușadattasya $\diamond$

${ }^{\circ}$ aggrabhișajā krrto yam sa(3)mucchrayo dharmmacakkrasya 1

darppaddhvajo yo makaraddhvajasya

na pātito (4) govrșabhaddhvajena $\diamond$

tam pāditam śakkyakuloddhvajena

${ }^{\circ}$ imena cakkrena sa(5)dharmmajena 2

mahātmanā kamisanisūdanena

na sūdito yo madhusūdanena

(6) sa sūdito rāganisūdanena

doșāsuro cakkravarenimena 3

māyāśarīrā(7)ranisammbhavena

tenottamadhyānagunendhanena $\diamond$

jñānārccișā kleśamahāvanāni

(8) dagdhani cakkrena ${ }^{\circ}$ imena tena 4

tam ${ }^{\circ}$ erisam cakkam mahāsenapatisarame nam(9)dimnakasa $\diamond$ deyadhammam ${ }^{\circ}$ apaṇo nivānasambambharatha[tā]yā thāpitam bhadamitadhe(10)masenena ${ }^{\circ}$ amnuṭitam ? ? [jānāa tu sa[dev]ā[s]u[ra]mānuso loko ${ }^{\circ}$ iti $\|$

"Success! In the $18^{\text {th }}$ year, in the $3^{\text {rd }}$ fortnight of winter, on the $3^{\text {rd }}$ day.

1. The chief physician of King Śri--Rudrapurusadatta of well-known blazing fame carried out this erection of a dharma wheel.

2. The banner of pride of the one with makara banner (= Kāma) that was not felled by the one with bull banner (= Siva), that one has been felled by the descendant of the Śakya family by means of this wheel born together with the dharma.

3. The demon of hatred that was not killed by the mighty killer of Kamsa (= Krṣna), killer of Madhu (= Viṣnu), that one was killed by the killer of passion by means of this excellent wheel. 
4. The great forests of defilements have been burned by him with the flame of knowledge that has the qualities of the highest dhyan $a^{56}$ as fuel and its origin in the fire stick that is the body of Māyā, by means of this very wheel.

May the world with gods, demons and men know ... that this wheel endowed with such qualities is a donation by Nandinnaka in the Monastery of the Great General, erected for the sake of bringing about his own nirvanna, and effected by the Venerable Dhammasena!"

The introductory part (opening and date) and the four stanzas of the inscription (lines 1 to the middle of line 8) are written in Sanskrit, the concluding part (the middle of line 8 to line 10) in Prakrit. The first stanza is in Āryā meter, the other three stanzas in Tristubh meter (2-3 Upajāti, 4 Indravajrā). The Sanskrit deviates only subtly from the classical norms in a number of ways noted by previous editors: doubling of

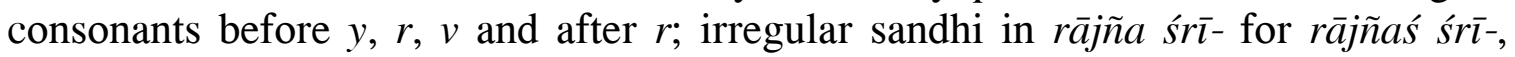
doṣāsuro cakkra-for dveșāsuraś cakkra-, cakkravarenimena and cakkrena imena. We may add imena instead of anena in the last two examples, the use of accusative instead of locative case in the dating formula (following the Prakrit convention) and the gender of dhvaja alternating between masculine and neuter. Those preparing the inscription appear to have made an effort to write class nasal plus stop in the Sanskrit part (sometimes preceded by additional anusvāra: 1 hemaimnta-, 7 -sammbhavena, endhanena), but use anusvāra plus stop only in the Prakrit part (9 sambharatha[nā]yā, bhadamta-). Occasional spelling mistakes are noted below.

110 8: The date is clearly year 18. It was so read by Munirathnam 2005 (M) and Ramesh \& Muniratnam 2011-12 (R\&M). Skilling \& von Hinüber 2011 (S\&H) have $106,{ }^{57}$ but corrected their reading to 108 in von Hinüber 2013b: $366(\mathrm{H}) .{ }^{58}$ The historical implications of this reading are noted above.

1 -dipta-: So read by M, but S\&H and R\&M have -dipta-. The reading seems certain, however, and should be treated as one of several very minor spelling mistakes from the point of view of classical Sanskrit. The integrity of the meter is not affected by short $i$ in this word, which probably allowed it to persist through the production process of the text into the final inscription.

\footnotetext{
${ }^{56}$ We leave the word dhyanna untranslated since none of the many English equivalents satisfactorily conveys the traditional double meaning of this technical term expressed by Buddhaghosa in his Visuddhimagga (ed. Warren \& Kosambi, p. 121) as follows: ārammanūpanijjhānato paccanīkajhāpanato vā jhānam "dhyāna (has its name alternatively) from reflecting on objects or from burning up enemies." Our verse draws simultaneously on both meanings: uttamadhyāna probably refers to the highest of the four levels of meditative absorption that set the ground for the Buddha's Awakening, whereas the metaphorical frame of verse 4 clearly builds on the meaning of dhyanna as fiery power obliterating enemies (similar to the non-Buddhist notion of tapas). It is interesting that the double meaning of the term, building as it does on the Middle Indo-Aryan phonetic merger of the roots $\sqrt{d h y} \bar{a}$ and $\sqrt{k s} \bar{a}$, remains operative in the incipient Sanskrit environment that our inscription reflects.

${ }^{57}$ As did Skilling 2008: 97-98 in his initial report on Phanigiri, based on a visit in 2005.

${ }^{58} \mathrm{We}$ only discuss earlier readings in detail where the most recent edition (S\&H with corrections in $\mathrm{H})$ differs from our interpretation.
} 
2 rājña for rājñas: So read by R\&M. M and $\mathrm{H}$ read rājñno, S\&H răjñ [o], but an ending $-o$ would constitute incorrect sandhi. We therefore prefer to consider rājña

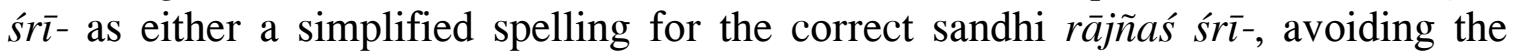
three-part conjunct śśr, or as a phonetic simplification. ${ }^{59}$

4 päditam. The reading is clear, but lexically we expect pātita-, as in the preceding pāda. Skilling \& von Hinüber 2011: 9 suggest that the confusion of $t$ and $d$ may betray a Dravidian background of the engraver (or rather original scribe) of the inscription. While this is possible, we consider a Middle Indo-Aryan source of the confusion equally likely since intervocalic Old Indo-Aryan [t] and [d] had begun to merge into [ð] well before the time of our inscription.

4 śakkyakuloddhvajena: So read by $\mathrm{M}$ and RM, and after inspection of the original stone there can be no doubt that this reading is correct (fig. 10). This rules out S\&H's interpretation, based on the reading kuleddhvalj]ena (Skilling \& von Hinüber 2011: 9, n. 5), in terms of as a learned compound with inflected prior member (aluksamāsa). We would like to propose a tentative alternative interpretation of sakkyakuloddhvajena as śakkyakulo(r)ddhvajena "scion of the Śākya family," with omitted $r$ in -ürddhva-, either as accidental Prakritism (note śakkya-for śakkya-in the same word) or as intentional "imprecise spelling" in the Sanskrit-Prakrit grey area that was meant to bring the word in question closer the instances of -ddhvaja"banner" in this stanza and create a punning relationship (ślesa) with them. A meaning "later" for $\bar{u} r d h v a$ is well-attested, making the interpretation of $\bar{r}$ rhvaja as 'born later, scion' at least possible. The dictionaries do not appear to list this meaning for the compound, but MW s.v. "being higher, upper" and PTSD s.v. uddhaja "upright, honest ... (v.l. for pannadhaja)" at least show the possible semantic breadth of the compound. A third, less involved, interpretation, would be to take śakkyakulo simply as prior member of a compound with $o$ instead of $a$, but while such compound spellings are well-attested in Gāndhārī (e.g., acaliobhava-, cf. Baums 2009: 236), we have no reason to expect them in our inscription.

4-5 sadharmmajena: $\mathrm{M}$ and $\mathrm{S} \& \mathrm{H}$ initially read sa dharmmajena as two words, but both editors later corrected themselves to $\mathrm{R} \& \mathrm{M}$ and $\mathrm{H}$ sadharmmajena. It would indeed be hard to construe independent $s a$, presumably as nominative singular masculine of the demonstrative pronoun, in the sentence in question. The problem would be not only that the referent darppadhvajo yo is already picked up by tamsee 8 imena tena for another case of pleonastic pronouns-but that the two pronouns in question here would be far apart from each other and disagree in their apparent gender and/or case (neuter nominative or masculine/neuter accusative tam vs. masculine nominative $s a$ ). Reading sadharmmajena, one is immediately tempted to emend sa(d)dharmmajena and understand "born from the good dharma," but this is made impossible by the meter which requires the first syllable of the word to be short. We seem to be left only with the possibility of interpreting $s a$ - as "together with" and translate "this wheel born together with the dharma," the solution also adopted by von Hinüber 2013b: 366. The intended meaning would then be that the

${ }^{59}$ Cf. Wackernagel 1896: 342-343 (§ 287c). 
dharma and its symbol the wheel originated at the same time when the dharma was first promulgated (the dharmacakrapravartana).

6-7 māyāśarīrāranisammbhavena: So read by $\mathrm{R} \& \mathrm{M}$ and, in the slight variant māyāśarīrāranisammbhavena, by $\mathrm{S} \& \mathrm{H}$. The original reading in $\mathrm{M}$ was māyāśarīrāranim sammbhavena, but both absence of anusvāra and retroflex nasal in -äranii-are clear. We think we can offer a significant improvement in the interpretation of the imagery expressed by this word. Skilling \& von Hinüber 2011: 8 translated the entire phrase māyāsáärāranisammbhavena tenottamadhyānagunendhanena jñānārccișā as "by the spark which is insight, (the spark) that arose from the kindling wood which is his magic (illusory?) body, by this fire wood which is virtue, the deepest meditation." They go on to suggest that the term māyāsarīra, which they concede to be unattested elsewhere, might either be a general reference to the insubstantial nature of the Buddha's physical body or even refer directly to the buddhological concept of the nirmānakāya. There is a syntactic problem with their interpretation in that māa $\bar{a}-$ śarīrāranisammbhavena and tenottamadhyānagunendhanena are both very likely to

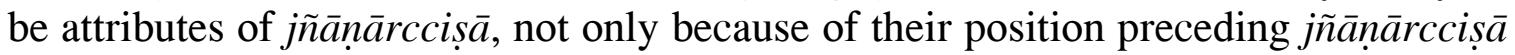
but also because in the real world the production of fire required both firesticks and fuel. A less problematic interpretation of māyāśarīrārani-suggests itself if we simply take $m \bar{a} y \bar{a}$ to be the name of the Buddha's physical mother Māyā and remember that arani "(lower) firestick" is an established metaphorical expression for a mother with reference to the process of sexual intercourse and conception (MW s.v.). The overall phrase would then amount to a perfectly balanced comparison of the Buddha's knowledge (jñanna) as arising from the physical condition of his birth from his mother Māyā's body (māyāśarīra) and the further condition of his highest meditative absorption (uttamadhyāna), with a flame (arcis) arising from the combination of firestick (arani) and fuel (indhana). The mention of the Buddha's mother Māyā in stanza 4 further provides a link with the specification of his further ancestry as the Śākya family in stanza 2, neatly bracketing the three Tristubh verses describing the Buddha and his accomplishments. The archeological context of the pillar would have contributed in bringing the Buddha's mother to the mind of a learned reader of this inscription since the pillar appears to have been established in proximity to a majestic torana in the decorative program of which the birth of Sākyamuni features prominently. ${ }^{60}$ We cannot entirely rule out that a learned double entendre was intended by the composer of the verse by using the compound māyāsarîra. We know that the docetic buddhology set forth, for instance, in the Lokānuvartanāsūtra, was current among the Śaila schools of Āndhradeśa, at least by the time of Candrakīrti (ca 600-650), but possibly earlier. ${ }^{61}$ At the moment, however, we do not know which

\footnotetext{
${ }^{60}$ Cf. Skilling 2008: 102-103 and fig. 11. The same relief is also reproduced on the reverse of the cover of Subrahmanyam et al. 2008.

${ }^{61}$ As shown by Harrison (1982), an echo of this influential and early sūtra of the Bodhisattvayāna may be found in Nāgārjuna's Niraupamyastava, while Candrakīrti cites verses from this scripture, in Prakrit, which he identifies as the Ägama of the Pūrvaśailas. On the issue of the integration of this scripture in the canons of the Mahāsāmghikas, see Tournier forthcoming a. For quotations and echoes of this sūtra in the Mahāparinirvāna-Mahāsütra, yet another scripture possibly connected with Āndhradeśa, see Radich 2015: 53, n. 109.
} 
monastic lineage(s) were present in Phanigiri. In the absence of any supporting evidence from the site that would suggest that religious figures such as Dhammasena might have been familiar with such docetic trends, we consider it preferable to adopt the simpler interpretation of this compound.

8 dagdhani: $\mathrm{M}$ read dagdhāni, $\mathrm{R} \& \mathrm{M}$ similarly da[gdhā]ni and $\mathrm{S} \& \mathrm{H}$ dagdh $[\bar{a}] n i$. There does not, however, seem to be a length mark on the second akșara, and we prefer to treat this as an orthographic slip.

8 tam ${ }^{\circ}$ erisam: $\mathrm{M}$ and R\&M read tam varisam without explanation. S\&H read tamdharisam and translated "which accompanies [the pillar]," but it is unclear to us how their translation follows from their reading. Presumably -dharisam would somehow be derived from the root $d h r$ "to hold," but in fact it is the pillar that holds the cakra rather than vice versa. On closer inspection of the original stone, however, it seems clear to us that the second akșara is ${ }^{\circ} e$ rather than dha (fig. 11). This suggests an interpretation as two words, the second of which corresponds to Old Indo-Aryan idriśa "such a one," i.e., a cakra exactly as just described in the four Sanskrit verses. Middle Indo-Aryan forms of this word with $r$ are common (cf. CDIAL s.v. $\bar{d} d r s a$ s), but in light of the general closeness of the Ikșvāku Prakrit inscriptions to Pali it is interesting to note that the normal Pali form is edisa with $d$.

8-9 mahāsenapatisarame namdimnakasa: $\mathrm{M}$ read mahāsenapati saramenam dinokasa and $\mathrm{R} \& \mathrm{M}$ mahāsenapati saramenamdinakasa. While both of these readings correctly recognized the presence of a Great General, they remained syntactically incoherent. $\mathrm{S} \& \mathrm{H}$ healed the syntactic problem with their reading mahāsenapatisa ramanamdinokasa, but were left with a problem of two donors that they described as follows: "The general Ramanamdinoka donated the cakra to be raised and put on a pillar erected by the physician." They had noted earlier: "Strangely enough, the physician does not mention his name. This, however, is perhaps again due to the metre." ${ }^{62}$ We may add as a third problem, not addressed by Skilling \& von Hinüber, that the place or institutional recipient of the donation would not be mentioned. It seems to us that all of these problems can be solved by dividing words as we do and assuming vowel sandhi in mahāsenapatisarame (= mahāsenapatisa arame $)^{63}$ which then specifies the donation or institutional recipient of the donation as the Monastery of the Great General. The title mahāsenāpati figures very prominently in the Ikșvāku inscriptions from Nagarjunakonda where it is applied to members of the royal house. This in turn makes it possible to interpret namdimnakasa as the name of the heretofore nameless physician, who was then the donor of both the cakra and, secondarily, the pillar on which the cakra was mounted (as indeed specified in stanza 1). Following the usual pattern in the Ikșvāku corpus, his Indo-Aryan name Nandi is extended by a suffix -innaka-.

9-10 bhadamtadhemasenena: M, R\&M read bhadamta dhemasenena, $\mathrm{S} \& \mathrm{H}$ bhadanta [be]masenena. The first word clearly uses anusvāra instead of class nasal

\footnotetext{
${ }^{62}$ Skilling \& von Hinüber 2011: 10-11.

${ }^{63}$ We cannot cite precisely analogous cases of this sandhi in our corpus. But it would be entirely unsuspicious in literary Pali, and this is a decidedly literary inscription. Note sammāsambudhaseti in EIAD 29 cited below.
} 
(fig. 12), as throughout the Prakrit portion of this inscription (see above). The name of the venerable monastic representing his institution at the donation was in all likelihood Dhammasena, with the apparent $e$ mātrā in our inscription as a misspelling for anusvāra. The name Dhammasena is known from another Phanigiri inscription (EIAD 105, edited in von Hinüber 2012 and 2013a), though it remains unclear whether both refer to the same person.

10 [jāna $\bar{a} t u$ : $\mathrm{M}$ and $\mathrm{R} \& \mathrm{M}$ refrain from any reading in this part of the inscription, while $\mathrm{S} \& \mathrm{H}$ read .i ? ?. On close inspection (fig. 13) we are fairly certain of our reading proposed here, in which the special form of the $\bar{a}$ mātrā attached to $[j \bar{a}]$ was misinterpreted by $\mathrm{S} \& \mathrm{H}$ as their $i$ mātrā. The imperative third-person singular verb turns everything that precedes in the concluding formula into a dependent participial phrase.

10 sa[dev]ā[s]u[ra]mānuso loko: $\mathrm{M}$ read [sana] ... mānusalaka, R\&M more cautiously ... mānuso loko and S\&H [sa] ? ? ? mānuso loko. After inspection of the original stone (fig. 14), the reading proposed here-a known expression in Buddhist sources ${ }^{64}$ - seems very likely and provides the subject for the concluding sentence governed by $[j \bar{a} n \bar{a}] t u$.

\section{EIAD 114}

This is engraved on an ayaka pillar of which only a lower fragment has been recovered. It is currently mounted on the western ayaka platform of the heavily restored Great Caitya. We are unable to ascertain whether this was the original location of the pillar. The pillar fragment is $31.5 \mathrm{~cm}$ wide, and the original width of the piece appears to have been only slightly greater (fig. 15). The fragment contains the last two lines of a donative inscription very similar in script to a Nagarjunakonda inscription dating from year 6 of the reign of the Sātavāhana king Gotamīputa SiriVijayasātakanni that is the earliest dated inscription found at that site. ${ }^{65}$ The present inscription may likewise belong to the pre-Ikșvāku period. Each line is cut off in the middle of the last aksara, and only traces remain of the third line from the bottom. To our knowledge, this inscription has not been previously published, and we present here our original reading and interpretation. The extant lines are exceptionally well preserved and can be confidently transcribed and translated as follows:

(1) $++? ?+? / / /$

(2) gahapatikasa tummakasa bhayaya budhamnikā[ya]

(3) deyadhammam bhagavato mahāpugalasa [ti]

"(...) Meritorious gift to the Bhagavant, the Great Man, by Budhannikāa, wife of the householder Tummaka."

\footnotetext{
${ }^{64}$ E.g., Mahāvastu (ed. Senart) II 232.20 vismayam loka āpanno sadevāsuramānuṣo and the Gāndhārī *Manasvināgarājasūtra (ed. Strauch 2014: 74; CKM 266 in Baums \& Glass ongoing) manaspio ca nagarayo sadevamanușasaro ? +.

${ }^{65}$ EIAD 1. See Sarkar 1965-66: 273-274; Raghunath 2001: 67 (no. 1); Nagarjunakonda Museum, acc. no. 79 .
} 
The name of the donor bears the same typical regional suffix (here -annik $\bar{a}$ - with retroflex nasal) that we already saw in Nandinnaka, the name of the donor of the previous inscription. In the present one it is apparently attached to the Indo-Aryan base Buddhā. The etymology of the name of Buddhannikā's husband Tummaka remains obscure. Also as in Phanigiri inscription EIAD 104, we have here the term deyadhamma used to designate the donated object, and both inscriptions likewise end in the quotative particle $t i$. The term mahappugala is, as far as we can see, only used here in the epigraphic corpus of early Āndhradeśa; it can be compared, however, to 'agapogala "Highest Man," found in two Nagarjunakonda inscriptions. ${ }^{66}$ Only the indistinct descenders of three akșaras are preserved in our line 1, providing no hint what the preceding part of the inscription may have contained. Judging from EIAD 104 discussed above, and from the formulaic repertoire of the Āndhra corpus and Buddhist donative inscriptions in general, we would have expected a date, a specification of the object that constitutes the donation, a location, and possibly also an institutional recipient. The last in particular would have been very welcome since none of the Phanigiri inscriptions available to us so far contain the name of the local Buddhist school. As more of the Phanigiri corpus is published, and possibly also additional discoveries are made, we hope that light will eventually be cast also on this and other aspects of the local history of this important Buddhist site.

\section{An ayaka pillar inscription from the Great Caitya at Nagarjunakonda and the interpretation of the term dhätuvaraparigahita}

The remaining remarks of this report will focus on the group of ayaka pillars of the Great Caitya (mahācetiya) established under the sponsorship of a close-knit group of donors led by Cāntisirī. This figure was the uterine sister of king Vāsithīputa SiriCāntamūla, the wife of dignitary Vāsithīputa Kandasiri, and became, between the $6^{\text {th }}$ and the $18^{\text {th }}$ regnal year of Siri-Vīrapurisadata, this king's mother-in-law. She is recorded as primary donor for twelve inscriptions of this group, and is systematically mentioned even in those cases where she is not herself the donor. In total, the remains of as many as eighteen out of the original set of twenty āyaka pillars that would have surrounded the Great Caitya have been recovered during excavations, and all of them are inscribed. Vogel knew of seventeen ayaka pillars recovered from this site, being unaware of EIAD 11, published for the first time by Raghunath. ${ }^{67}$ There remain to this day three unpublished inscriptions of this series, to which we have assigned the numbers EIAD 16, 19 and $41{ }^{68}$

This group of inscriptions within the Nagarjunakunda corpus contains closely related texts: all contain the exact same date and record donations either by Cāntisirī or by one of her associates. The serial nature of these inscriptions calls for a systematic comparison of their texts, in order to assess formulaic fluctuations and to better determine the meaning of several difficult words. As a contribution to that end,

\footnotetext{
${ }^{66}$ EIAD 1 (see preceding note) and 80 (Vogel 1929-30a: 25).

${ }^{67}$ Raghunath 2001: 85-86, no. 8A.

${ }^{68}$ These three unpublished inscriptions were known to Vogel, and correspond respectively to nos. A2, A4, and D3 in his list of inscriptions (Vogel 1929-1930a: 13-14).
} 
we present here our edition of the best preserved among the three unpublished pillar inscriptions (EIAD 19): this will lead us to revisit the interpretation of a muchdebated epithet of the Buddha, namely dhātuvaraparigahita.

The inscription edited here is preserved in three separate fragments of a single pillar. The first fragment, bearing accession number NM 289, is kept in the main storage of the site museum (fig. 16): it is a fragment from the upper part of the pillar, bearing the left part of the first three lines as well as the rightmost akșara of the first line (figs. 17 and 18). The second fragment (NM 678), likewise kept in the main storage of the site museum, contains most of the first four lines, and a part of the fifth (fig. 19). A third fragment, without accession number known to us, is currently accessible on the southern ayaka platform of the reconstructed mahascaitya on the island in Nagarjuna Sagar: ${ }^{69}$ it contains parts of the fifth line, and lines 6 to 11 (figs. 20). Between 1926 and 1928, three estampage sheets were prepared for these fragments and sent to Jean-Philippe Vogel, then professor of Sanskrit at Leiden University, where they are still preserved as part of collections of the Kern Institute at the University Library, under abklatsch number N15 (fig. 21). ${ }^{70}$ Vogel decided not to publish a separate edition of this inscription, but instead to record variant readings of this and other inscriptions in the critical apparatus of his edition of another inscription. ${ }^{71}$ Our edition of the inscription was prepared on the combined basis of the Leiden estampages and of digital photographs that we took on site.

\section{EIAD 19}

(1) sidham namo bhagavato devarājasakatasa supabudhabodhino ${ }^{72}$ savaminuno savasatānukampa[ka]sa (2) jitarāgadosamohavipamutasa mahāganivasabhagaminhahathisa sammasambudhasa dhātuvara(3)parigahitasa ${ }^{\circ}$ imammhi mahācetiye mahārajasa virūpakhapatimahāsenaparigahitasa ${ }^{\circ}$ agi(4)(hota) $/ /{ }^{\circ}$ agithomavājapeyāsamedhayājisa hiramnnakotịgosatasahasahalasatasa///(hasapadāyisa) ${ }^{73}$ (5) (sa)///vathesu ${ }^{\circ}$ apatiha〈ta $\rangle$ samkkapasa vāsithīputasa ${ }^{\circ}$ ikhākusa siricāmtamūlasa sodarā bhagini (6) [ra](m)ño māọhariputasa sirivira[pu]risadatasa pituchā mahāsenāpatisa mahātalavarasa vāsiṭhīputasa (7) pūkiyānam kadasirisa bhariyā samaṇabamhaṇakavaṇavanijakad̄̄nānugahavailāmikadānapaṭibhā(8)gavochinadhārapadāyini savasādhuvachalā mahādānapatini mahātalavari khamiasāgaramṇakamātā (9) cāmitisiri ${ }^{\circ}$ apano ${ }^{\circ}$ ubhayakulasa $\quad{ }^{\circ}$ atichita-m-anāgatavațamānakānam parināmetuna

\footnotetext{
${ }^{69}$ This placement appears to be historically incorrect: if we may rely on Vogel's list cited in the preceding footnote, the original location of pillar A4 was on the eastern platform.

${ }_{70}$ These three sheets bear the numbers IV-4-c/b/a. We have not yet determined what numbering system these refer to.

${ }^{71}$ Vogel 1929-1930a: 15-17, no. C3 (EIAD 4).

72 This precise compound does not appear to be otherwise attested in Pali, Gāndhārī or Sanskrit literature. The only attested syntagm consisting of suprabuddha- $+\sqrt{b u d h}$ appears to occur in the set of verses Dhammapada (ed. von Hinüber \& Norman) 296-301 supabuddham pabujjhanti, Khotan Dharmapada (ed. Brough, CKM 77 in Baums \& Glass ongoing) 100-105 supra ${ }^{\circ}$ udhu pra ${ }^{\circ}$ ujadi, Udānavarga (ed. Bernhard) 15.2-26 suprabuddham prabudhyante and Patna Dharmapada (ed. Cone) 241-243 suprabuddham prabujjhanti.

${ }^{73}$ This reconstruction, based on the parallels, assumes that this line continued over the fourth facet of the pillar, and that, similarly to line 6, 3 akșaras were written on that facet.
} 
${ }^{\circ}$ ubhayaloka(10)hitasukhanivāṇathanāya ${ }^{\circ}$ atano ca nivānasampatisamimpādake ${ }^{74}$ 'imam khambham savalokahitasukhanivāṇathanāya ca (11) patithapitam ti — ramiño si[r]iv[i]rapurisadatasa samiva $6\langle$ vāpa 6$\rangle$ diva 10

"Success! Homage to the Bhagavant, worshipped by the $\operatorname{king}(\mathrm{s})$ of the gods, who completely realized Awakening, the Omniscient One, who is compassionate towards all beings, who conquered and is released from lust, hatred and delusion, the bull and rut elephant among great leaders, the Perfect Buddha who is dhätuvaraparigahita! At this Great Caitya, Cāntisirī—uterine sister of Great King Vāsiṭ̂̄puta Siri-Cāntamūla the Ikṣvāku, favored by Mahāsena who has Virūpākṣa as his lord, sacrificer of the Agnihotra, the Agniștoma, the Vājapeya and the Aśvamedha, giver of tens of millions of (pieces of) gold, hundreds of thousands of cows and hundreds of thousands of plows (of land), whose will is unimpeded in all matters; paternal aunt of King Mātharīputa Siri-Vīrapurisadata; wife of Great General, Great Talavara Vāsithīputa Kandasiri of the Pūkīyas; giver of an unequalled and uninterrupted stream of velämika ${ }^{75}$ gifts as a favor to ascetics, brahmans, beggars, mendicants and the wretched; affectionate to all good people; great donor; Great-Talavara-wife, mother of Khandasāgarannaka-having dedicated (the merit) to the past, future and present members of her family on both sides, established this pillar for the sake of well-being and happiness in both worlds and of nirvāna, and for achieving the fortune of nirvanna for herself, for the sake of the well-being, happiness and nirvanna of all people. In the $6^{\text {th }}$ year of King Siri-Virapurisadata, in the $6^{\text {th }}$ fortnight of the rainy season, on the $10^{\text {th }}$ day."

Vogel proposed to take the whole string of epithets of the Buddha, opening the inscription, as being governed by namo and, under the influence of Louis de La Vallée Poussin, translated the last epithet, dhātuvaraparigahitasa, as "absorbed by the best of elements, i.e., by nirvāna." Hirananda Sastri, the editor of the Epigraphia Indica volume in which Vogel's contribution appeared, was tempted to take it as qualifying mahācetiye, and freely translated "protected by the corporeal remains of

\footnotetext{
${ }^{74}$ As far as we are aware, the term nibbānasampatti is only attested in Pali literature. In the Khuddakapātha (ed. Smith) 7, stanza 13, and later in the atthakathās, it commonly occurs as part of a triad, together with manussasampatti and dibbasampatti.

${ }^{75}$ As already suggested by Vogel (1929-30a: 33), this epithet appears to point to the brahmin Velāma, identified as a former rebirth of Śākyamuni, who is commonly invoked in Buddhist texts as an archetype of generosity. His numerous gifts, already listed in a story of the past embedded in the Velāmasutta of the Anguttara-Nikāya, 'seemed to be flowing like rivers' (najjo maññe vissandati; AN IV 393.16-394.7). In a retelling of this passage in the Khadirangārajātaka, the Buddha says he has given away the seven jewels, when born as Velāma, 'as if making into one stream the five great rivers' (pañca mahānadiyo ekoghapunnami katvā viya; Ja I 228.18-24). The characterization of this meritorious deed-also known as Velämamahāyañña-as a continuous stream is clearly echoed in the description of Cāntisirī. The hypothesis that a version of the Velāma story circulated in Āndhradeśa is moreover strengthened by the fact that a narrative panel bearing the label jätaka velamiya was found in Kanaganahalli (Nakanishi \& von Hinüber 2014: 85, no. III.1, 5; von Hinüber 2016: 12). On the Velāmajātaka, see also, in an earlier volume of this Bulletin, Terral-Martini 1959.
} 
the Buddha." ${ }^{, 76}$ The issue was eventually revisited by Gregory Schopen who in 1988 dedicated a whole article to the understanding of this epithet. Schopen identified two problems in its interpretation: a syntactic one, whether dhatuvaraparigahitasa is governed by namo or by mahācetiye; and a semantic one, what is the referent of dhatuvara. Schopen argued elaborately in favor of the interpretation of the problematic epithet as forming a syntactic unit with the preceding sammasambudhasa and the following mahācetiye, and consequently translated as follows: "At the Great Shrine of the Perfectly Enlightened One who is enclosed within the most excellent relic." 77

Let us reconsider briefly both the syntactic and the semantic arguments put forward by Schopen. First, the present edition of the EIAD 19 puts into perspective the following statement by Schopen, in favor of the interpretation that mahācetiye governs dhätuvaraparigahitasa: ${ }^{78}$

although almost all of the Nāgārjunikoṇda inscriptions open with or contain a namo invocation consisting of strings of different epithets of the Buddha, the collocation sammmāsambudhasa dhātuvaraparigahitasa occurs only in inscriptions that make reference to the mahācetiya and always immediately precedes the noun mahācetiya in the locative.

This last statement is clearly erroneous, since the text of EIAD 19 and of three other pillar inscriptions (EIAD 14, 17 and 18) insert the pronoun ima( $\dot{m}) m h i$ before mahācetiye. ${ }^{79}$ This version of the formula, preserved in four out of the fourteen inscriptions of the set that preserve the phrase in the beginning of the text, establishes a clear syntactic break between the opening invocation and the ensuing statement of location. The four instances of the pronoun moreover all feature on pillars dedicated by Cāntisirī, the main donor of the mahäcetiya. It is impossible to know with certainty which version of the formula—with or without ima $(\dot{m}) m h i-$ might have stood in the master copy of this group of pillar inscriptions. Nevertheless, considering the fact that the majority of inscriptions do not include the pronoun, it is not unreasonable to suppose that it was added by some of the agents involved in the process of copying the text onto stone, and hence to consider it an addition, aiming at clarifying a syntactic ambiguity. While none of the four inscriptions preserving the pronoun were separately published at the time Schopen wrote in 1988, Vogel had in fact duly recorded the variants of all four records in the apparatus to his edition of inscription C3 (EIAD 4); his translation of that record was also probably informed by his assessment of the variants at hand. ${ }^{80}$ By contrast, the alternative interpretations of the syntax suggested by Sastri and, after him, by Schopen, appear to have overlooked the apparatus carefully compiled by the Dutch scholar.

\footnotetext{
${ }^{76}$ Cf. Vogel 1929-1930a: 29, with n. 1.

${ }^{77}$ Schopen 1988: 535.

${ }^{78}$ Schopen 1988: 529 (the italics are present in the original; the underlining marks our emphasis).

${ }^{79}$ See respectively Raghunath 2001: 95-96, no. 10A; 97-98, no. 10B (erroneously reproduced as a separate inscription, pp. 101-102, no. 10D); 99-100, no. 10C.

${ }^{80}$ Vogel 1929-1930a: 16, n. 3.
} 
A look at opening invocations addressed to the Buddha in the Nagarjunakonda corpus shows that sammāsambudhasa frequently occurs towards the end of a string of epithets. EIAD 29 makes this particularly clear, as it opens with namo bhagavato savasatotamasa sammāsambudhaseti, where the iti neatly marks the transition between the invocation and the central part of the record. ${ }^{81}$ Given this parallel, sammäsambudhasa is most naturally taken to have stood at the end of the invocations included in the âyaka pillars, and Schopen's assumption of a separation between the preceding epithets in the genitive singular and this one appears to be artificial. To us it seems most likely that, as in EIAD 29, sammāsambudhasa as well as dhätuvaraparigahitasa agree with the initial bhagavato. These three epithets are inseparably connected in three further records, two pillar inscriptions from the Great Caitya, and one slab inscription found in the apsidal temple (cetiyaghara) founded by Cāntisirī to the east of the main shrine. The two pillar inscriptions (Vogel $\mathrm{X}$ and B2, EIAD 13 and 15) are the only ones of the eighteen pillars not to contain an opening invocation of the Buddha: after sidham, the records open directly with a phrase depicting the donor-respectively Cāntisirī and Aḍavi-Cāntisirī, sister of the ruling king. Only later on, apparently as an afterthought, the location of the gift is made explicit in these terms: ${ }^{82}$

bhagavato sammasambudhasa dhātuvaraparigahitasa mahācetiyamhi

"...at the Great Caitya of the Bhagavant, the Perfect Buddha who is dhàtuvaraparigahita..."

The slab inscription (Vogel E, EIAD 28) opens with a short invocation to the Buddha, before locating the gift in the apsidal temple instead of the Great Caitya. ${ }^{83}$ Later on, in recording the dedication of a stone pavilion, the gift is located "at the foot ( $p \bar{a} d a m \bar{u} l a)$ of the Great Caitya of the Bhagavant, the Perfect Buddha who is dhâtuvaraparigahita." ${ }^{4}$ Schopen cites the two inscriptions known to him as confirmation of his interpretation of the syntax of the common formula. But the

\footnotetext{
${ }^{81}$ For other instances in which (sammāsami)budhasa appears in conclusion of an invocation, with recapitulative force, see EIAD 20, 44-46 and 51. These inscriptions are Vogel 1929-30a: 22-24 (F, G, H); Vogel 1931-32: 62-63 (G2 and G3); Raghunath 2001, nos. 11, 27-29 and 34.

${ }^{82}$ Variant readings from EIAD 13, 1.8 (Vogel 1929-30a: 14, item X; Raghunath 2001: 89, no. 9A) and EIAD 15, 1.6 (Vogel 1929-1930a: 13 and 18, item B2; Raghunath 2001: 93, no. 10): sambudhasa] EIAD 13; -sabudhasa EIAD 15 - dhātuvara-] EIAD 15; thātuvara EIAD 13 • mahācetiyamhi] EIAD 13; mahācetiye EIAD 15.

${ }^{83}$ Cf. EIAD 28, 1.1 (Vogel 1929-1930a: 21): namo bhagavato $\diamond$ budhasa cetiyaghara mahāraja[sa v]i[rüpakhapat]imahāsenaparigahitasa... . By contrast with Vogel who took cetiyaghara as a nominative singular, we follow here the suggestion of Sircar (1942: 227 n. 2; 1965: 236 n. 3) in interpreting it as a mistake for cetiyaghare. This is supported by the similarity of construction with the pillar inscriptions, where mahäcetiye opens the main sentence after the opening invocation. Other inscriptions found in the ruins of the apsidal temple site contain similar texts, but they are all damaged and are of no assistance in this matter. Cf. EIAD 24-27 (Sarkar 1969: 176-177); EIAD 39 (Vogel 1931-1932: 66-69, no. M2 + M9).

${ }^{84}$ Cf. EIAD 28, 1. 2 (Vogel 1929-30: 21): bhagavato sammasa[m்]budhasa dhātuparigahitasa ma《hā 》cetiyapādamūle.
} 
evidence may just as well be interpreted to the contrary, as an indication of the fact that bhagavato, sammasambudhasa, and dhätuvaraparigahitasa should, in all occurrences, be taken together. It is significant that the least elaborate version of the opening invocation of the Buddha, among the pillar inscriptions of the Great Caitya, opens precisely with the same three epithets-and these only-in four pillar inscriptions. ${ }^{85}$ It would be highly problematic to translate these instances in any other way than "Homage to the Bhagavant, the Perfect Buddha who is dhätuvaraparigahita!" Having clarified the syntax of the formula, we can now turn to the problem of the meaning and referent of the problematic compound. First, it should be stressed that dhatuvaraparigahita is not the only compound formed with parigahita (var. parigahīta, Skt. parigrhìta) in this group of inscriptions. Most importantly, the compound virüpakhapatimahāsenaparigahita features prominently among the epithets of the mahārāja Siri-Cāntamūla. In EIAD 19, as in all inscriptions dedicated by Cāntisiri at the Great Caitya and which include any epithets of this king, the two compounds ending in parigahita occur in immediate vicinity, and should thus, if possible, be interpreted together. ${ }^{86}$ The interpretation of mahāsenaparigahita has been revisited recently by Richard Mann who, following a suggestion of his teacher Phyllis Granoff, suggested to translate the compound as "the one favoured (parigrhìta) by Mahāsena, who has the one with deformed eyes (virūpāksa) as his lord," seeing in Virūpākșa a possible reference to Śiva ${ }^{87}$ It should be noted, though, that— to a Buddhist audience at least—Virūpākha could also have brought to mind the figure of one of the cāturmahärājikadevas, the four great kings protecting the directions of the cosmos, and serving as tutelary figures for human kings. ${ }^{88}$ In this context, it might be worth mentioning that one of the most frequent epithets of the Buddha, occurring in ten of the fourteen pillar inscriptions that contain the opening invocation, is devarajjasakatasa. If that epithet is understood, broadly speaking, as referring to the kings among gods (and not specifically to Indra), then such a category would encompass the cāturmahāräjikadevas. This could thus constitute a veiled allusion to the superiority of the Buddha (who is dhātuvaraparigahita) over the lower gods, to whom king Siri-Cāntamūla was attached. This in turn would be in line with the rhetoric of superiority of the Buddha deployed with respect to two major non-Buddhist deities in the epigraphical poem

${ }^{85}$ Cf. EIAD 7 (Vogel 1929-30: 20-21, item C5); EIAD 14 (Raghunath 2001: 95-96, no. 10A); EIAD 17 (Raghunath 2001: 95-96, no. 10A; 97-98, no. 10B = ibid. 101-102, no. 10D); EIAD 41 (unpublished). All four inscriptions open with sidham namo bhagavato sammasambudhasa dhätuvaraparigahitasa. Schopen (1988: 528), who could have known only the first of these inscriptions, believed that the shortest version of the invocation was sidham namo bhagavato devarājasakatasa sammasambudhasa dhātuvaraparigahitasa.

${ }^{86}$ Schopen mentions only in passing (1988: 534) that parigahita occurs within the compound mahāsenaparigahita, but does not attempt to find an interpretation of both compounds in the light of each other. We are grateful to Richard Salomon for having pointed out to us (Seattle, April 2013) that herein lies an important weakness of Schopen's interpretation.

${ }^{87}$ Mann 2012: 168-169.

${ }^{88}$ Virūpākșa is generally put in charge of the western direction, although in some versions of this fluid system he watches over the south. Cf. Tournier forthcoming $b$. 
from Phanigiri (EIAD 104) discussed above. ${ }^{89}$ While the meaning of parigrhita as "favored" by such a person or deity is well attested in inscriptions, ${ }^{90}$ the Nagarjunakonda corpus also uses the same verbal adjective in the sense of "received" (suparigahita regularly describes the recipients of a gift) or 'surrounded'-for instance in the description of a mandapa being surrounded by a quadrangular compound (cātusāla). ${ }^{91}$ In Buddhist terminology, moreover, parigrhīta commonly means "realised" or "comprehended," operative in the compound dhätuvaraparigahita, especially if it is possible to take $d h \bar{a} t u$ as pointing to something quite different than relics. In this connection, Schopen categorically states that "in contemporaneous or-by Indian standardsnearly contemporaneous Buddhist donative inscriptions, dhātu always and unambigously appears to mean 'relic'.", ${ }^{93}$ While dhātu indeed commonly occurs in the sense of "relic" in Indian Buddhist inscriptions, often concerned with the dedication of stūpas or caityas, the affirmation that dhātu always has this meaning is contradicted (twice) by at least one inscription alluded to by Schopen in support of his affirmation, namely the important—and admittedly difficult—Gāndhārī inscription of Senavarman (CKI 249 in Baums \& Glass ongoing). In this inscription, as noticed by Schopen, the relics (G. dhadu) established in the stūpa are characterised as "pervaded by virtue, pervaded by concentration, wisdom, and by the seeing and knowledge of liberation" (śilaparibhavita samasiprañavimutiñanadrasa $\{$ na paribhavita), a last epithet which, incidentally, points to the realization by a Buddha-or an arhant—of nirvāna. What Schopen failed to notice is that, immediately after this characterisation-and in perfect agreement with their characterization as vimutiñanadraśa nna>paribhavita-these relics are described as "gone to the realm of nirvanna, that is the most excellent place of the Tathāgata" (tadagadaprava〈ra〉diśanivanadhatugade). ${ }^{94}$ The Senavarman inscription thus offers an instance where the possibility must be assumed of learned play on the double

\footnotetext{
${ }^{89}$ Note also that such a claim, made by Buddhists, about the superiority of their founder, finds an echo in the phraseology of non-Buddhist inscriptions on the site. The Sanskrit inscription EIAD 65, recording the installation, by an official of the Ābhīra king Vașușena, of an image of Aștabhujasvāmin (a form of Viṣnu), opens as follows: namo bhagavato $\diamond$ devaparamadevasya $\diamond$ purānapurușasya $\diamond$ nārāyanasya, which Sircar translates: "Salutation to Lord Nārāyaṇa who is the supreme god among the gods and the Primordial Male" (Sircar 1961-62: 202, and p. 203). On this inscription see the recent publication by Salomon (2013).

${ }^{90}$ It may be noted here that the use of parigahita in the compound mahāsenaparigahita in a way anticipates similar constructions with name of a deity + pādānudhyāta/pādānudhyāna in Sanskrit inscriptions from Āndhradeśa, also commonly used in Gupta inscriptions. On the alternation between and equivalence of both these constructions, see Sircar 1966: 238; Ferrier \& Törsök 2008.

91 Both meanings were already discussed in Schopen 1988: 534, with references to relevant inscriptions. On compounds in -parigraha see also Fussman 1999: 569-574.

${ }^{92}$ Cf. BHSD s.v.

${ }^{93}$ Cf. Schopen 1988: 530.

${ }^{94}$ Cf. von Hinüber 2003: 23, 1. 7; Baums 2012: 228, 231. The reconstruction prava $\langle$ ra $\rangle$ follows the suggestion of von Hinüber 2003: 27. For an alternative interpretation, see Baums 2012: 231, n. 71. Bailey 1980: 23, Fussman 1982: 8 and Salomon 1986: 270 translate nivanadhatugada- as "possessing the material basis (dhātu-) of nirvāna-," "qui sont des éléments de nirvāna" and "gone to the root of nirvāna," each time as attribute of the relics.
} 
meaning of $d h \bar{a} t u$. This is moreover confirmed by yet another passage of the same inscription, where the merit generated by the establishment of these relics is assigned with the phrase "they/one may come to rest/disappear in that deathless realm" (amudae dhatue nivatato). ${ }^{95}$ In other words, there seems to be a conscious equation, in the inscription of Senavarman, between the state realized by the Buddha with his body, ascribing power to what will remain of it after his parinirvanna, and the state wished for by the donor.

If we can take the liberty, after Schopen, of using a $1^{\text {st }}$-century inscription from Gandhāra to shed light on a $4^{\text {th }}$-century inscription of Āndhradeśa—on the assumption that, "by Indian standards," they are nearly contemporaneous-then we are likewise free to resort to inscriptions left by the successors of the Ikșvākus in this region, in our attempt to use the epigraphic record to elucidate the use of the word dhātu in the Nagarjunakonda corpus. It will here suffice to mention that Viṣnukundin Govindavarman (I or II), in an exceptional record of his lavish support to Buddhists preserved in a copper-plate inscription from Tummalagudem, presents himself as having "conceived the great thought of Awakening in order to save the whole realm of sentient beings (sattvadhatu). ${ }^{96}$ While we do not wish to suggest that the use of dhātu in the Nagarjunakonda corpus actually pointed to the pair sattvadhātu/dharmadhātu, commonly featuring in Mahāyānasūtras, ${ }^{97}$ this and the earlier evidence from the Senavarman inscription add nuance to Schopen's assessment of the evidence.

To be sure, the evidence presented so far does not necessarily contradict the possibility of interpreting dhātuvaraparigahita as "enclosed"-or, as we would prefer to translate, "ensconced"- "within the most excellent relic," but it seems clear enough that it is far from the only way of interpreting the compound. In particular, the possibility to see in dhätuvara an allusion to nirvānadhätu is all the more tempting in that nirvanna is systematically mentioned in the inscriptions dedicated by Cāntisirī as the ultimate aim towards which the merits produced by her generosity are dedicated. In the inscription EIAD 19, which offered the concrete occasion for this elaborate discussion, the word nirvanna occurs as often as three times, so it is difficult to maintain that such a notion was not on the minds of those who composed this record. It is therefore tempting to think that, as in the Senavarman inscription, the description of the state realized by the Buddha and that aimed at by the donor reflected each other. In light of such a parallel, dhātuvaraparigahita can be tentatively translated as "who is embraced by the most excellent realm [of nirvāna]."

\section{Conclusion}

We have presented above some of the results of the first year of our work, and notably of our first weeks of fieldwork in Telangana and Andhra Pradesh. While our research began with the specific aim of publishing a corpus of Ikșvāku inscriptions-

${ }^{95}$ Cf. von Hinüber 2003: 37, 1. 12; Baums 2012: 229, 232.

${ }^{96}$ Cf. Sankaranarayanan 1977, no. I (Tummalagudem plates), p. 154, 1. 12: ... sakalasatvadhātutrānāyotpāditamahābodhicigtena (corr. -cittena)... . On this inscription (EIAD 174), see Tournier in progress.

${ }^{97}$ On this pair of concepts, see recently Silk 2015: 19-41. 
and this we indeed hope to do in the near future-our experience in the field has led us to broaden our scope and to envisage a comprehensive corpus of the Early Inscriptions of Āndhradeśa. We stand only at the beginning of this multi-year endeavor, that we hope will be undertaken in progressively closer cooperation with our academic colleagues as well as with archaeological authorities in India. Nevertheless, it seems clear already from these first results how much can be gained from intensive and systematic field survey for the quality of philological work on these important historical documents. It has also become clear how substantially existing reference works fall short of presenting a complete picture of the epigraphical record for the early, predominantly Buddhist, phase of the history of this region, and that we may still look forward to substantial advances in our knowledge.

\section{List of figures}

Fig. 1: Places mentioned in this report. Map by Pierre Pichard.

Fig. 2: Slab from Ghantasala bearing a label inscription (EIAD 128 A) encircled by śankhalipi (EIAD $128 \mathrm{~B})$.

Fig. 3: Close-up showing EIAD 128 A.

Fig. 4: Label inscription from Ghantasala (EIAD 125).

Fig. 5: Limestone mandapa pillar from Kantamanenivarigudem, near Guntupalli.

Fig. 6: Lateral face of the mandapa pillar from Kantamanenivarigudem.

Fig. 7: Inscribed part of the mandapa pillar from Kantamanenivarigudem (EIAD 220).

Fig. 8: Octagonal pillar from Phanigiri, its upper part on the left.

Fig. 9: Inscribed part of the octagonal pillar from Phanigiri (EIAD 104).

Fig. 10: Close-up of the middle portion of line 4 of EIAD 104.

Fig. 11: Close-up of the middle portion of line 8 of EIAD 104.

Fig. 12: Close-up of the end of line 9 of EIAD 104.

Fig. 13: Close-up of the middle portion of line 10 of EIAD 104.

Fig. 14: Close-up of the end of line 10 of EIAD 104.

Fig. 15: Inscribed āyaka pillar from Phanigiri, after reconstruction (EIAD 114).

Fig. 16: Three large fragments of ayaka pillars in the main storage at Nagarjunakonda. The one closest to the wooden cases is NM 298, bearing small parts of EIAD 19.

Fig. 17: Close-up of the leftmost akșaras of lines 1-3 of EIAD 104.

Fig. 18: Close-up of the last akșara of line 1 of EIAD 104.

Fig. 19: Fragment NM 678 of the a yaka pillar bearing EIAD 19.

Fig. 20: Lower part of the ayaka pillar bearing EIAD 19 as preserved on the site.

Fig. 21: Three estampage sheets for EIAD 19 preserved at Leiden assembled in one photo.

\section{Abbreviations}

ARIE: Annual Report on Indian Epigraphy, Archaeological Survey of India BHSD: Buddhist Hybrid Sanskrit Dictionary (Edgerton 1953) 
CDIAL: Comparative Dictionary of the Indo-Aryan Languages (Turner 1966)

IAR: Indian Archaeology—A Review, Archaeological Survey of India

MW: A Sanskrit-English Dictionary (Monier-Williams 1899)

PTSD: The Pali Text Society's Pali-English Dictionary (Rhys Davids \& Stede 192125)

For Pali texts we follow the abbreviation system of von Hinüber 1996.

\section{Bibliography}

Bailey, H.W. 1980. "A Kharoșțī Inscription of Senavarma, King of Oḍi." The Journal of the Royal Asiatic Society of Great Britain and Ireland, 21-29.

Balbir, Nalini. 1994. "An investigation of textual sources on the samavasarana ('The Holy Assembly of the Jina')." In Festschrift: Klaus Bruhn zur Vollendung des 65. Lebensjahres dargebracht von Schülern, Freunden und Kollegen, edited by Nalini Balbir and Joachim K. Bautze, 67-104. Reinbek: Verlag für Orientalistische Fachpublikationen.

Baums, Stefan. 2012. "Catalog and Revised Texts and Translations of Gandharan Reliquary Inscriptions." In Gandharan Buddhist Reliquaries, 200-251. Gandharan Studies 1. Seattle: Early Buddhist Manuscripts Project.

Baums, Stefan, and Andrew Glass. Ongoing. Catalog of Gāndhārī Texts. https://gandhari.org/catalog.

Bendall, Cecil. 1897-1902. Çikshāsamuccaya: A Compendium of Buddhistic Teaching Compiled by Çāntideva Chiefly from Earlier Mahāyāna-Sütras. Bibliotheca Buddhica 1. St.-Pétersbourg: Académie impériale des sciences.

Bendall, Cecil, and W.H.D. Rouse. 1922. Sikshā-samuccaya: A Compendium of Buddhist Doctrine Compiled by Sāntideva Chiefly from Earlier Mahāyāna Sūtras. Indian Texts Series. London: John Murray.

Bénisti, Mireille. 1961. “À propos d'un relief inédit de Kârlâ.” Arts Asiatiques 8 (4): 263-270.

Bernhard, Franz. 1965-68. Udānavarga. Abhandlungen der Akademie der Wissenschaften in Göttingen, philologisch-historische Klasse, dritte Folge, Nr. 54 / Sanskrittexte aus den Turfanfunden, X. Göttingen: Vandenhoeck \& Ruprecht.

Brough, John. 1962. The Gāndhārī Dharmapada. London Oriental Series, Volume 7. London: Oxford University Press.

Cone, Margaret. 1989. "Patna Dharmapada, Part I: Text." Journal of the Pali Text Society 13: 101-217.

Edgerton, Franklin. 1953. Buddhist Hybrid Sanskrit Grammar and Dictionary. William Dwight Whitney Linguistic Series. New Haven: Yale University Press.

Falk, Harry. 1999-2000. "The Pātagaṇiguñdem Copper-Plate Grant of the Ikṣvāku King Ehavala Cāntamūla.” Silk Road Art and Archaeology 6: 275-283.

Ferrier, Cédric, and Judit Törzsök. 2008. "Meditating on the King's Feet? Some Remarks on the Expression pādānudhyāta." Indo-Iranian Journal 51 (2): 93113. 
Fussman, Gérard. 1982. "Documents Épigraphiques Kouchans, III: l'inscription de Senavarma, Roi d'Oḍi, Une Nouvelle Lecture." Bulletin de l'École Française d'Extrême-Orient 71: 1-46.

- 1999. "La place des Sukhāvatīvyūha dans le bouddhisme indien." Journal Asiatique 287 (2): 523-586.

Gadre, A.S. 1955-1956. "Brahmi Inscription from Salihundam." Epigraphia Indica 31: 87-88.

Ghosh, Suchandra. 2006. "Coastal Andhra and the Bay of Bengal Trade Network." South Asian Studies 22: 65-68.

Hanumantha Rao, B.S.L., N.S. Ramachandra Murthy, B. Subrahmanyam, and Īmani Śivanāgireḍi. 1998. Buddhist Inscriptions of Andhradesa. Secunderabad: Ananda Buddha Vihara Trust.

Harrison, Paul. 1982. "Sanskrit Fragments of a Lokottaravādin-Tradition." In Indological and Buddhist Studies: Volume in Honour of Professor J.W. de Jong on His Sixtieth Birthday, edited by and L.A. Hercus, 211-234. Canberra: Faculty of Asian Studies.

Hartmann, Jens-Uwe. 2015. "Poetry: South Asia." In Brill's Encyclopedia of Buddhism, edited by Jonathan A. Silk, Oskar von Hinüber, and Vincent Eltschinger, volume I, 532-540. Leiden: Brill.

von Hinüber, Oskar. 1996. A Handbook of Pāli Literature. Indian Philology and South Asian Studies 2. Berlin: de Gruyter.

- 2003. Beiträge zur Erklärung der Senavarma-Inschrift. Akademie der Wissenschaften und der Literatur, Abhandlungen der Geistes- und Sozialwissenschaftlichen Klasse, Jahrgang 2003 1. Stuttgart: Franz Steiner Verlag.

- 2012. "A Second Inscription from Phanigiri (Andhrapradesh): Dhammasena's Donation." Annual Report of the International Research Institute for Advanced Buddhology at Soka University for the Academic Year 2011 15: 3-10.

— 2013a. "Again on the Donation made by the Vinayadhara Dhammasena and on other inscriptions from Phanigiri." Annual Report of the International Research Institute for Advanced Buddhology at Soka University for the Academic Year 2012 16: 3-12.

— 2013b. "Behind the Scenes: The Struggle of Political Groups for Influence as Reflected in Inscriptions." Indo-Iranian Journal 56: 365-379.

. 2016. "Buddhist Texts and Buddhist Images: New Evidence from Kanaganahalli (Karnataka/India)." Annual Report of the International Research Institute for Advanced Buddhology at Soka University for the Academic Year 2015 19: 7-20.

von Hinüber, Oskar and K. R. Norman. 1995. Dhammapada. Oxford: The Pali Text Society.

ISO 15919. International Standard ISO 15919: Information and documentation, transliteration of Devanagari and related Indic scripts into Latin characters $=$ Information et documentation, translittération du Devanagari et des écritures 
indiennes liées en caractères latins. 2001. Geneva: International Organization for Standardization.

Khan, Mohammad Abdul Waheed. 1969. A Monograph on an Early Buddhist Stūpa at Kesanapalli (District Guntur, Andhra Pradesh). Edited by N. Ramesan. Archaeological Series 27. Hyderabad: Govt. of Andhra Pradesh.

Krishna Sastry, V.V. 1990. "Three Copper-Plate Grants of Prithvi-Sri Mularaja from Kondavidu." Journal of the Epigraphical Society of India (Bharatiya Purabhilekha Patrika) 16: 71-84, with pl. IV.

Longhurst, A.H. 1938. The Buddhist Antiquities of Nāgārjunakonda, Madras Presidency. Memoirs of the Archaeological Survey of India 54. Delhi: Manager of Publications.

Mann, Richard D. 2012. The Rise of Mahāsena: The Transformation of SkandaKārttikeya in North India from the Kușāna to Gupta Empires. Brill's Indological Library 39. Leiden: Brill.

Monier-Williams, Monier. 1899. A Sanskrit-English Dictionary Etymologically and Philologically Arranged with Special Reference to Cognate Indo-European Languages. Oxford: Clarendon Press.

Munirathnam, K. 2005. "Rudrapurisadatta Inscription from Phanigiri." Journal of the Epigraphical Society of India (Bharatiya Purabhilekha Patrika) 32: 78-81.

Nagaraju, S. 1995. "Emergence of Regional Identity and Beginnings of Vernacular Literature: A Case Study of Telugu." Social Scientist 23 (10/12): 8-23.

Nakanishi, Maiko, and Oskar von Hinüber. 2014. Kanaganahalli Inscriptions. Annual Report of the International Research Institute for Advanced Buddhology, Soka University, 17 (2013), Supplement. Tokyo: International Research Institute for Advanced Buddhology, Soka University.

Owen, Lisa N. 2012. Carving Devotion in the Jain Caves at Ellora. Brill's Indological Library 41. Leiden: Brill.

Parabrahma Sastry, P.V., ed. 1975. Department of Archaeology and Museums, Andhra Pradesh: Annual Report on Epigraphy, 1967. Epigraphical Series 10. Hyderabad: Govt. of Andhra Pradesh.

- 1977. Inscriptions of Andhra Pradesh: Cuddapah District, Part I. Epigraphical Series 12. Hyderabad: Govt. of Andhra Pradesh.

Radich, Michael. 2015. The Mahāparinirvāna-Mahāsūtra and the Emergence of Tathāgatagarbha Doctrine. Hamburg: Hamburg University Press.

Raghunath, K. 2001. The Ikșvākus of Vijayapuri (A Study of the Nagarjunakonda Inscriptions). Delhi: Eastern Book Linkers.

Ramesh, K.V., and K. Muniratnam. 2011. "Phanigiri Inscription of Rudrapurushadatta." Epigraphia Indica 43 (1): 75-77.

Rhys Davids, T. W., and William Stede. 1921-25. The Pali Text Society's PaliEnglish Dictionary. London: Pali Text Society.

Rosen Stone, Elizabeth. 1994. The Buddhist Art of Nāgārjunakonda. Buddhist Traditions 25. Delhi: Motilal Banarsidass.

Salomon, Richard. 1986. "The Inscription of Senavarma, King of Oḍi." Indo-Iranian Journal 29: 261-293. 
_. 2013. "Aștabhujasvāmin: A Reinterpretation of the Ābhīra Inscription from Nagarjunakonda." Indo-Iranian Journal 56 (3-4): 397-417.

Sankaranarayanan, S. 1967-1968. "Rentala Pillar Inscription of Siri-Chantamula I, Year 5." Epigraphia Indica 37: 29-32.

. 1974. "Two Vishṇukuṇi Charters from Tummalagudem." In Epigraphia $\bar{A}$ ndhrica Vol. II, edited by N. Venkataramanayya and P.V. Parabrahma Sastry, 4-20. Epigraphical Series 5. Hyderabad: Govt. of Andhra Pradesh.

- 1977. The Vishnukundis and Their Times: An Epigraphical Study. Delhi: Agam Prakashan.

—. 1977-1978. "Guntupalli Pillar Inscription of Śālankāyana Nandivarman." Epigraphia Indica 42: 75-96.

Sarkar, H. 1965-1966. "Nagarjunakonda Prakrit Inscription of Gautamiputra Vijaya Satakarni, Year 6." Epigraphia Indica 36: 273-274.

— 1969. "A Note on Some Fragmentary Inscriptions from Nagarjunakonda." Epigraphia Indica 38: 175-178.

Sarma, I.K. 1978. "Epigraphical Discoveries at Guntupalli." Journal of the Epigraphical Society of India (Bharatiya Purabhilekha Patrika) 5: 48-61.

- 1988. Studies in Early Buddhist Monuments and Brāhmī Inscriptions of $\bar{A} n d h r a d e ̄ s ́ a . ~ N a g p u r:$ Dattsons.

Sastri, T.V.G, M. Kasturi Bai, and M. Veerender. 1992. Vaddamanu Excavations, 1981-85. Hyderabad: Birla Archaeological \& Cultural Research Institute.

Schneider, Johannes. 2014. Eine buddhistische Kritik der indischen Götter: Śamkarasvāmins Devātiśayastotra mit Prajñāvarmans Kommentar. Wiener Studien zur Tibetologie und Buddhismuskunde. Wien: Arbeitskreis für Tibetische und Buddhistische Studien.

- 2015. "Eine buddhistische Sicht auf den Buddhāvatāra." Berliner Indologische Studien 22: 87-102.

Schopen, Gregory. 1988. "On the Buddha and His Bones: The Conception of a Relic in the Inscriptions of Nāgarjunikoṇạa." Journal of the American Oriental Society 108 (4): 527-537.

Senart, Émile. 1882-1897. Le Mahâvastu. 3 vols. Collection d'ouvrages orientaux / Société asiatique. Paris: Imprimerie nationale.

Sewell, Robert. 1880. Report on the Amarávati tope, and excavations on its site in 1877. London: Printed by G.E. Eyre and W. Spottiswoode.

Shimada, Akira. 2013. "Guntupalle: the oldest rock-cut Buddhist monastery in the eastern Deccan." In Living rock: Buddhist, Hindu and Jain cave temples in the western Deccan, edited by Pia Brancaccio, 61-75. Mumbai: Marg Foundation.

Shizutani Masao 静谷正雄. 1965. Indo Bukkyō Himei Mokuroku インド仏㸚碑銘目 錄. Kyōto: Heirakuji Shoten 平楽寺書店.

Silk, Jonathan. 2015. Buddhist Cosmic Unity. An Edition, Translation and Study of the Anūnatvāpūrnatvanirdeśaparivarta. Hamburg Buddhist Studies 4. Hamburg: Hamburg University Press.

Sircar, D.C. 1942. Select Inscriptions Bearing on Indian History and Civilization, vol. I. Delhi: Motilal Banarsidass. 
_ 1961-1962. "Nagarjunikonda Inscription of the Time of Abhira Vasushena, Year 30." Epigraphia Indica 34: 197-204.

— 1963-1964. "More Inscriptions from Nagarjunikonda." Epigraphia Indica 35: $1-36$.

- 1965. Select Inscriptions Bearing on Indian History and Civilization, vol. I. Second edition, revised and enlarged. Delhi: Motilal Banarsidass.

_. 1966. Indian Epigraphical Glossary. Delhi: Motilal Banarsidass.

—. 1969-1970. "Some Epigraphic and Manuscript Records, 1: An Alleged Inscription of Khāravela. 2: Buddhist Dhāran̄īs from China in Inscriptions and Manuscripts." Journal of Ancient Indian History 3: 30-49.

— . 1972-1973. "Indological Notes. 14: Kalinga-Mahișak-Ādhipati. 15: The Yavanas and Mathurā. 16: The Brahmavaivarta Purāna and the Vaidya Community of Orissa. 17: Further Observations on the Skandar and Siyān Inscriptions." Journal of Ancient Indian History 6: 166-178.

Sircar, D.C., and K.G. Krishnan. 1960-1961. "Two Inscriptions from Nagarjunikonda." Epigraphia Indica 34: 17-22.

Skilling, Peter. 1991. "A Buddhist Verse Inscription from Andhra Pradesh." IndoIranian Journal 34 (4): 239-246.

- 2008. "New Discoveries from South India: The Life of the Buddha at Phanigiri, Andhra Pradesh." Arts Asiatiques 63: 96-118.

Skilling, Peter, and Oskar von Hinüber. 2011. "An epigraphical Buddhist poem from Phanigiri (Andhrapradesh) from the time of Rudrapurușadatta." Annual Report of the International Research Institute for Advanced Buddhology at Soka University for the Academic Year 2010 14: 7-12.

Smith, H. 1978. The Khuddaka-Pātha together with its Commentary Paramattajjotikā I. London: Pali Text Society.

Somasekhara Sarma, M. 1974. "Some Prākṛit Inscriptions from Ghaṇtaśāla." In Epigraphia Āndhrica Vol. II, edited by N. Venkataramanayya and P.V. Parabrahma Sastry, 1-3. Epigraphical Series 5. Hyderabad: Govt. of Andhra Pradesh.

Srinivasan, P.R. 1965-1966. "A Brahmi Inscription from Gangaperuru.” Epigraphia Indica 36: 207-208.

_. 1973. "Some Brahmi Inscriptions from Guntupalli." Epigraphia Indica 39: 247-252.

Srinivisan, P. R., and S. Sankaranarayanan. 1979. Inscriptions of the Ikshvāku Period. Epigraphical Series 14. Hyderabad: The Government of Andhra Pradesh.

Strauch, Ingo. 2014. "The Evolution of the Buddhist Rakșa Genre in the Light of New Evidence from Gandhāra: The *Manasvi-Nāgaräja-Sūtra from the Bajaur Collection of Kharoșthī Manuscripts." Bulletin of the School of Oriental and African Studies 77 (1): 63-84.

Subrahmanyam, B., J. Vijaya Kumar, G.V. Rama Krishna Rao, and K.S.B. Kesava. 2008. Phanigiri: A Buddhist Site in Andhra Pradesh: An Interim Report, 2001- 
2007. Edited by P. Chenna Reddy. Archaeological Series 76. Hyderabad: Dept. of Archaeology and Museums, Govt. of Andhra Pradesh.

Subrahmanyam, R. 1964. Salihundam, a Buddhist Site in Andhra Pradesh. Archaeological Series 17. Hyderabad: Govt. of Andhra Pradesh.

- 1968. The Guntupally Brahmi Inscription of Kharavela. Epigraphical Series 3. Hyderabad: Govt. of Andhra Pradesh.

Suzuki Daisetz Teitaro, and Idzumi Hokei. 1949. The Gandavyūha Sūtra. New Revised Edition. Tokyo: The Society for the Publication of Sacred Books of the World.

Terral-Martini, Giselle. 1959. "Velāmajātaka." Bulletin de l'École française d'Extrême-Orient 49: 609-616.

Tournier, Vincent. Forthcoming a. La formation du Mahāvastu et la mise en place des conceptions relatives à la carrière du bodhisattva. Paris: EFEO.

- Forthcoming b. "Protective Verses for Travellers: A Fragment of the Diśāsauvastika-gāthās Related to the Scriptures of the MahāsāmghikaLokottaravādins." In Buddhist Manuscripts, volume IV, edited by J. Braarvig. Oslo: Hermes Publishing.

- In progress. "A Tide of Merit: Royal Patrons, Tāmraparnīya monks, and the Buddha's Awakening in 5th-6th century Āndhradeśa."

Tsukamoto Keishō 塚本啓祥. 1996, 1998, 2003. Indo Bukkyō himei no kenkyū イン ド仏教碑銘の研究 (A comprehensive study of the Indian Buddhist inscriptions). 3 vols. Kyōto: Heirakuji Shoten平楽寺書店.

Turner, R.L. 1966. A Comparative Dictionary of the Indo-Aryan Languages. London: Oxford University Press.

Vogel, J.Ph. 1929-1930a. "Prakrit Inscriptions from a Buddhist Site at Nagarjunikonda.” Epigraphia Indica 20: 1-36.

—. 1929-1930b. "Two Additional Inscriptions from Nagarjunikonda." Epigraphia Indica 20: 37.

—. 1931-1932. "Additional Prakrit Inscriptions from Nagarjunikonda." Epigraphia Indica 21: 61-71.

—. 1947-1948. "Prakrit Inscriptions of Ghaṇtaśālā." Epigraphia Indica 27: 1-4.

Wackernagel, Jacob. 1896. Altindische Grammatik. Band I: Lautlehre. Göttingen: Vandenhoeck und Ruprecht.

Warren, Henry Clarke, and Dharmananda Kosambi. 1950. Visuddhimagga of Buddhaghosâcariya. Harvard Oriental Series, Volume Forty-One. Cambridge, Massachusetts: Harvard University Press. 
Fig. 1: Places mentioned in this report. Map by Pierre Pichard

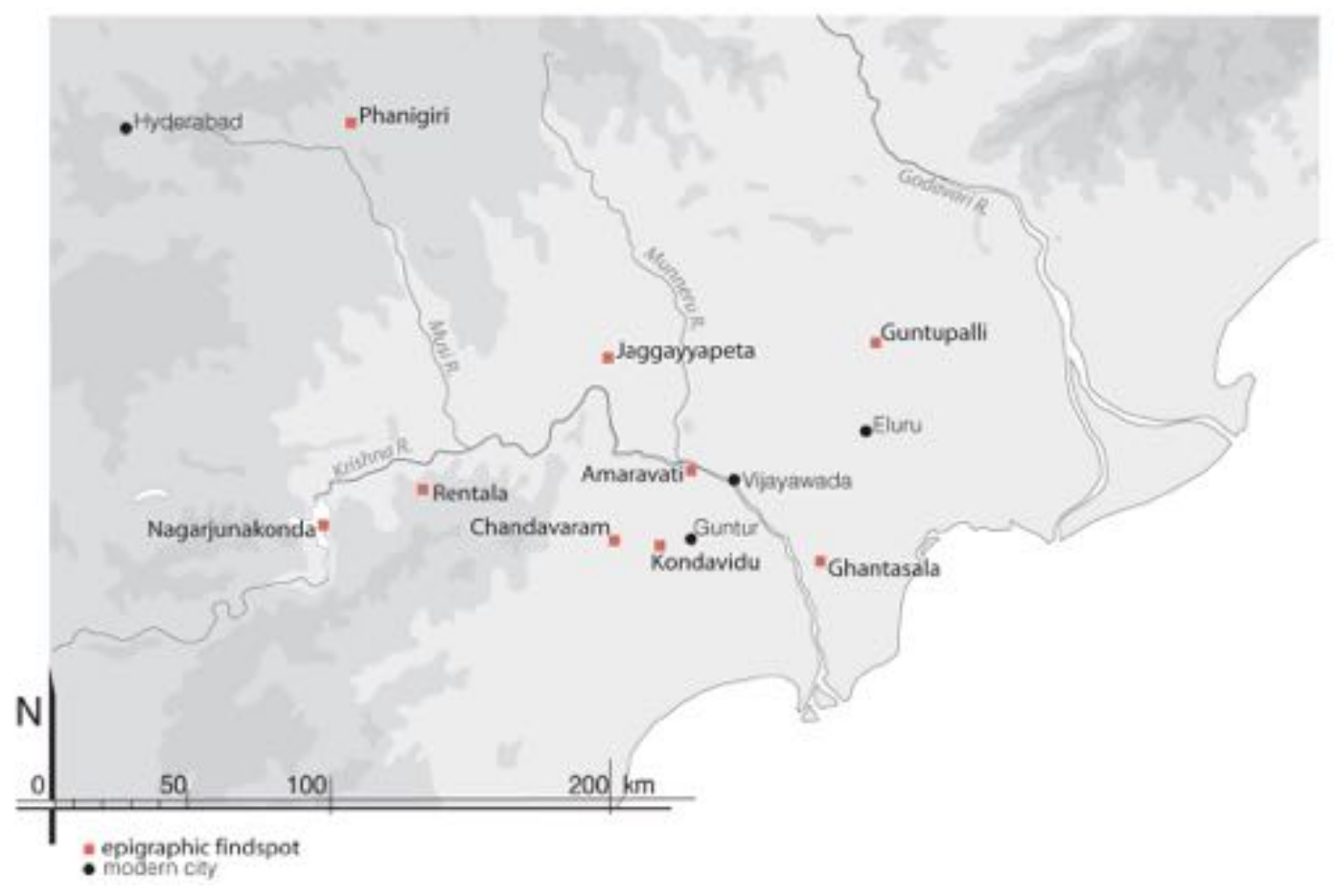

Fig. 2: Slab from Ghantasala bearing a label inscription (EIAD $128 \mathrm{~A}$ ) encircled by śankkhalipi (EIAD 128 B)

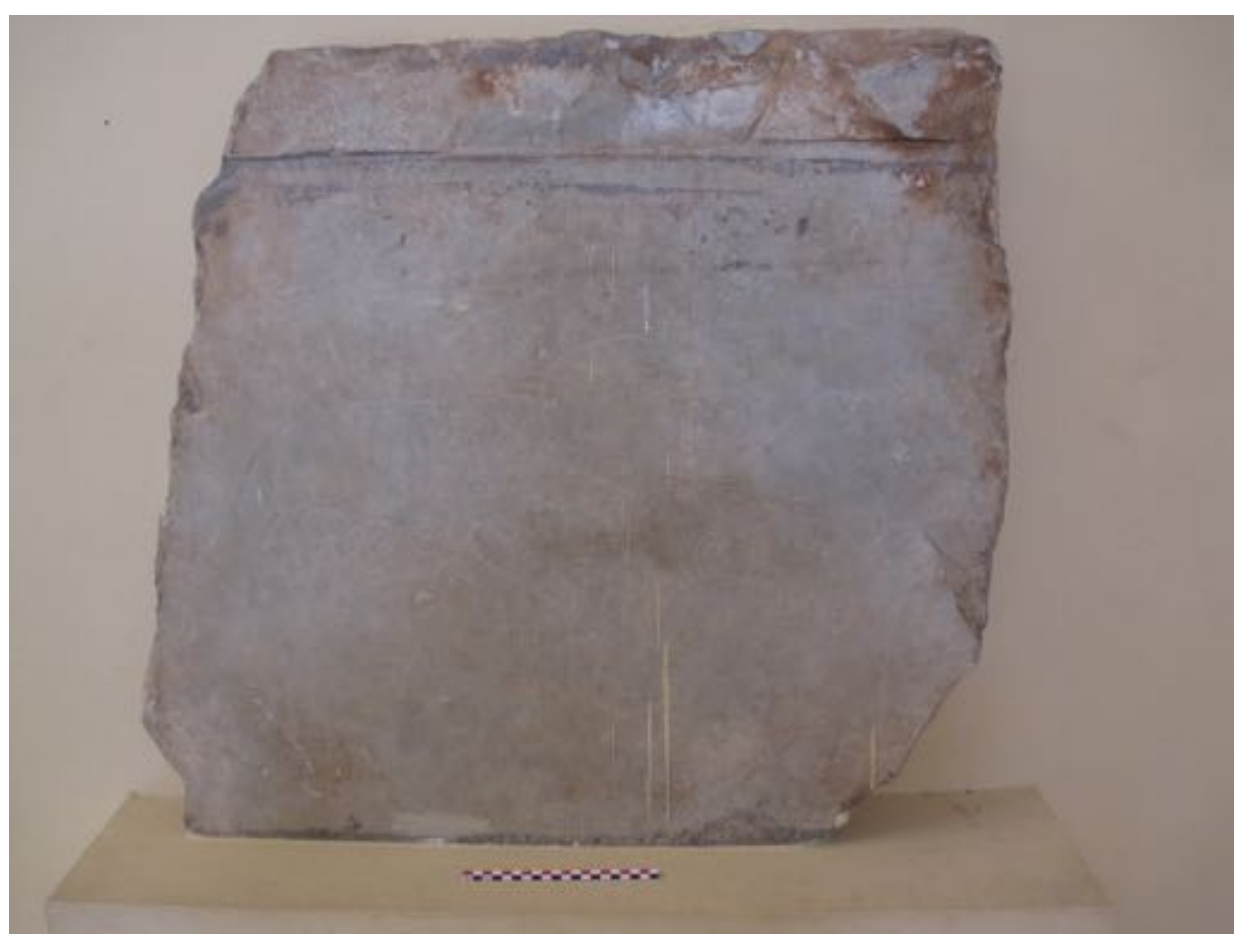


Fig. 3: Close-up showing EIAD 128 A

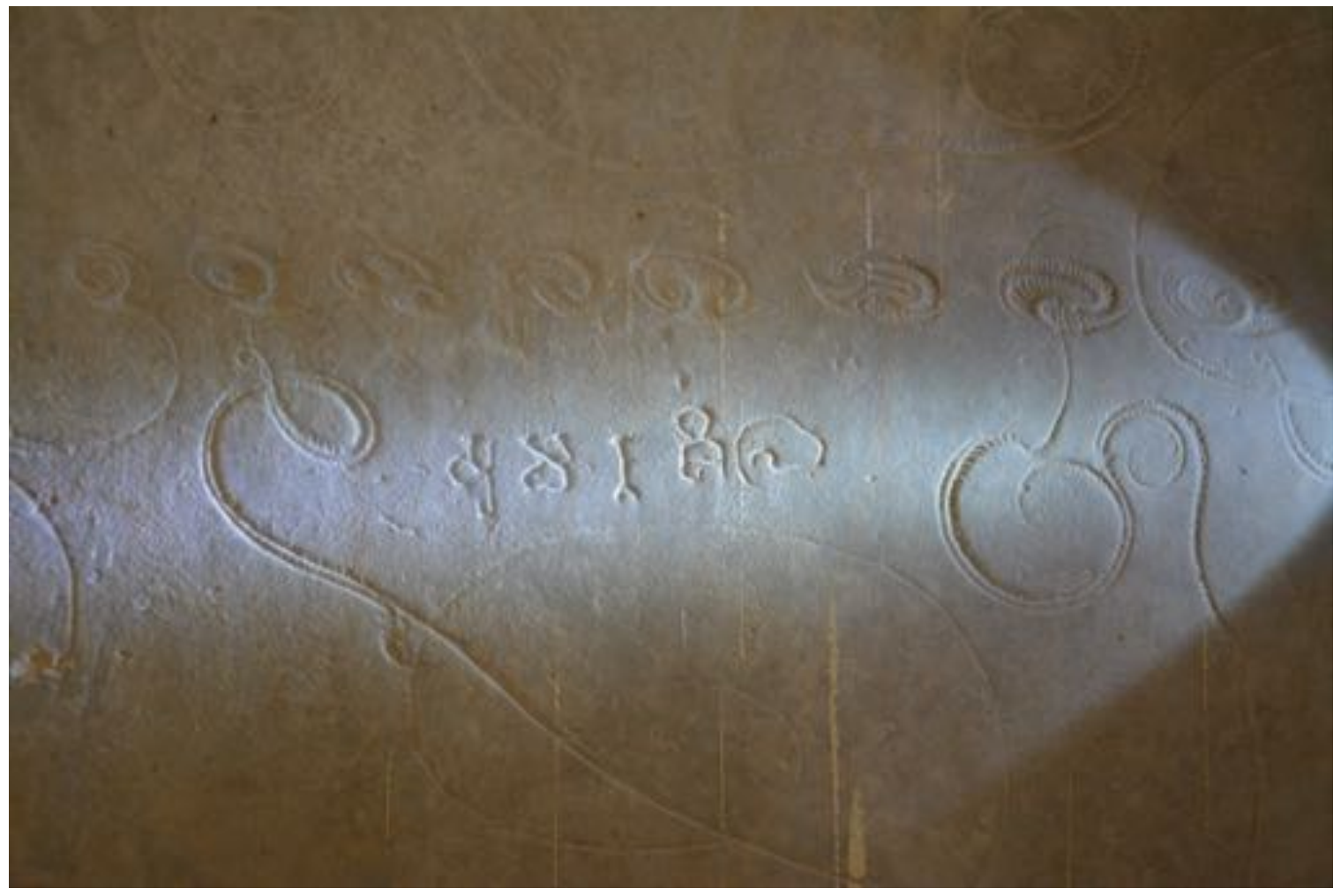

Fig. 4: Label inscription from Ghantasala (EIAD 125)

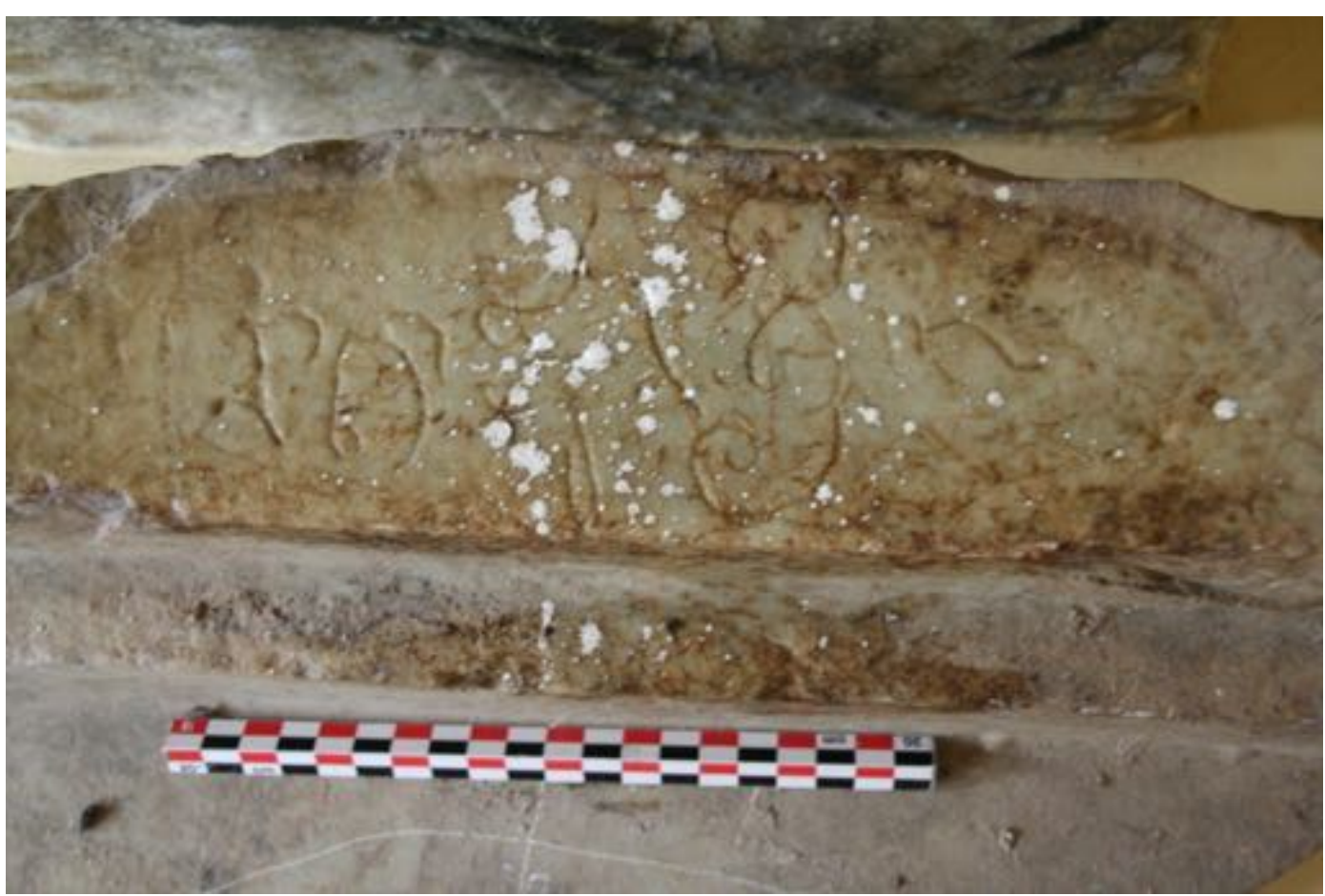


Fig. 5: Limestone mandapa pillar from Kantamanenivarigudem, near Guntupalli

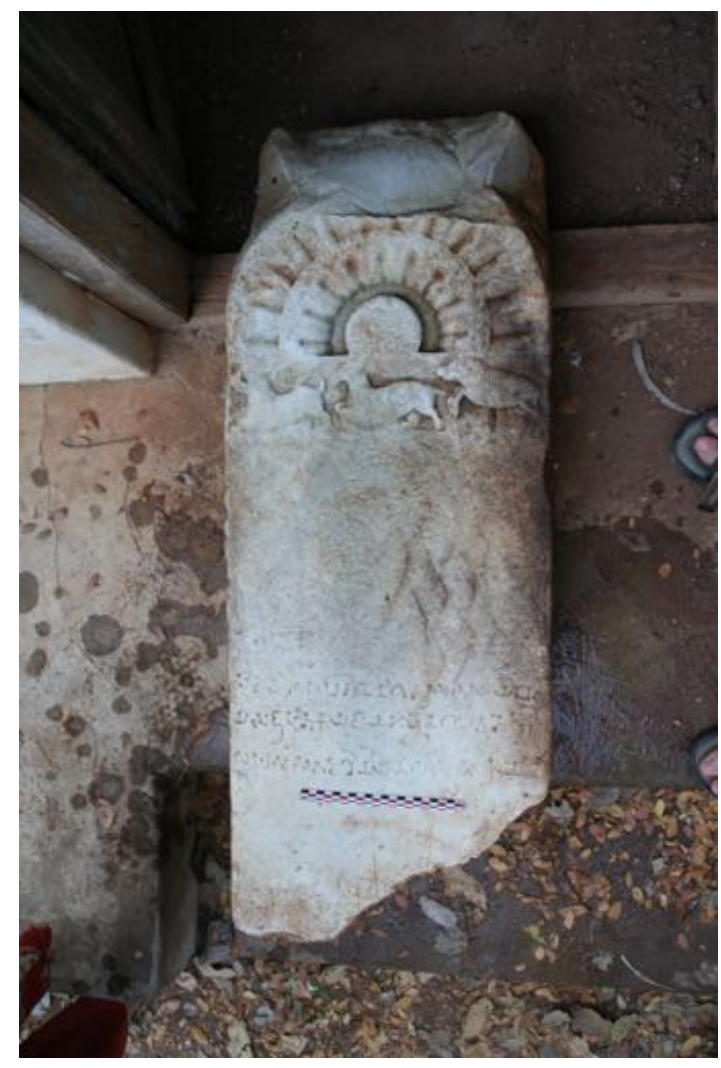

Fig. 6: Lateral face of the mandapa pillar from Kantamanenivarigudem

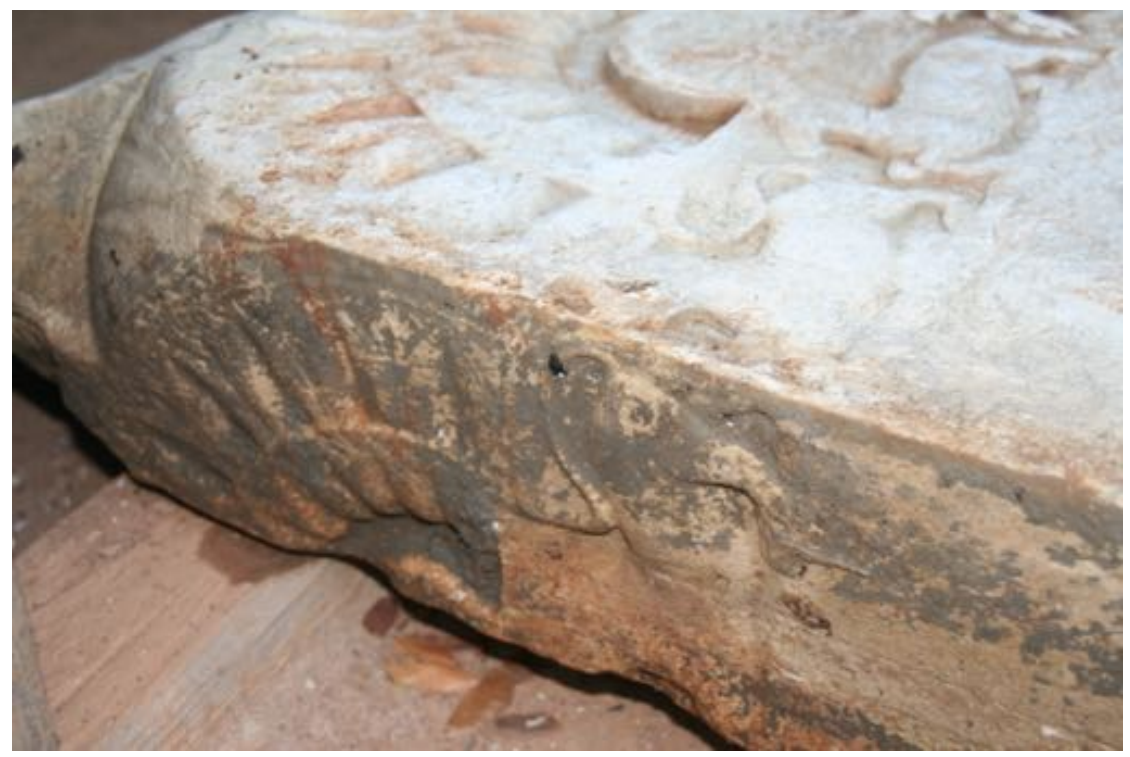


Fig. 7: Inscribed part of the mandapa pillar from Kantamanenivarigudem (EIAD 220)

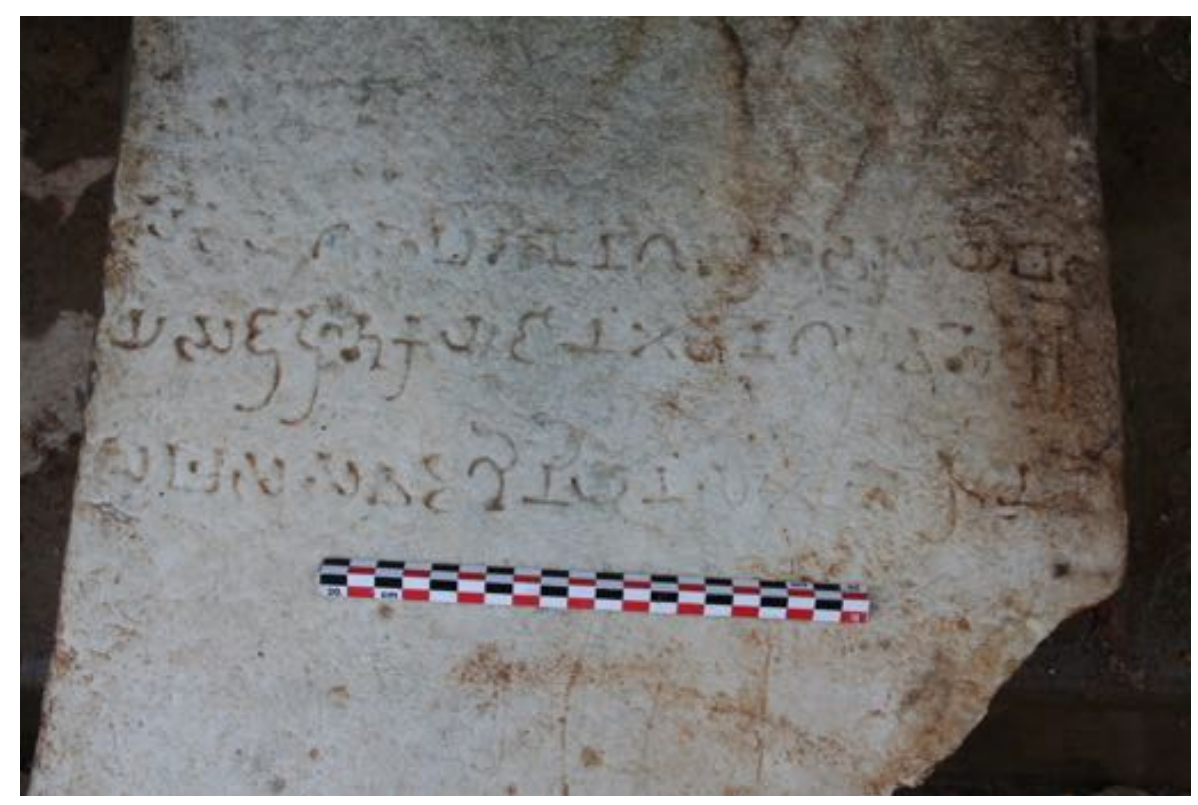

Fig. 8: Octagonal pillar from Phanigiri, its upper part on the left

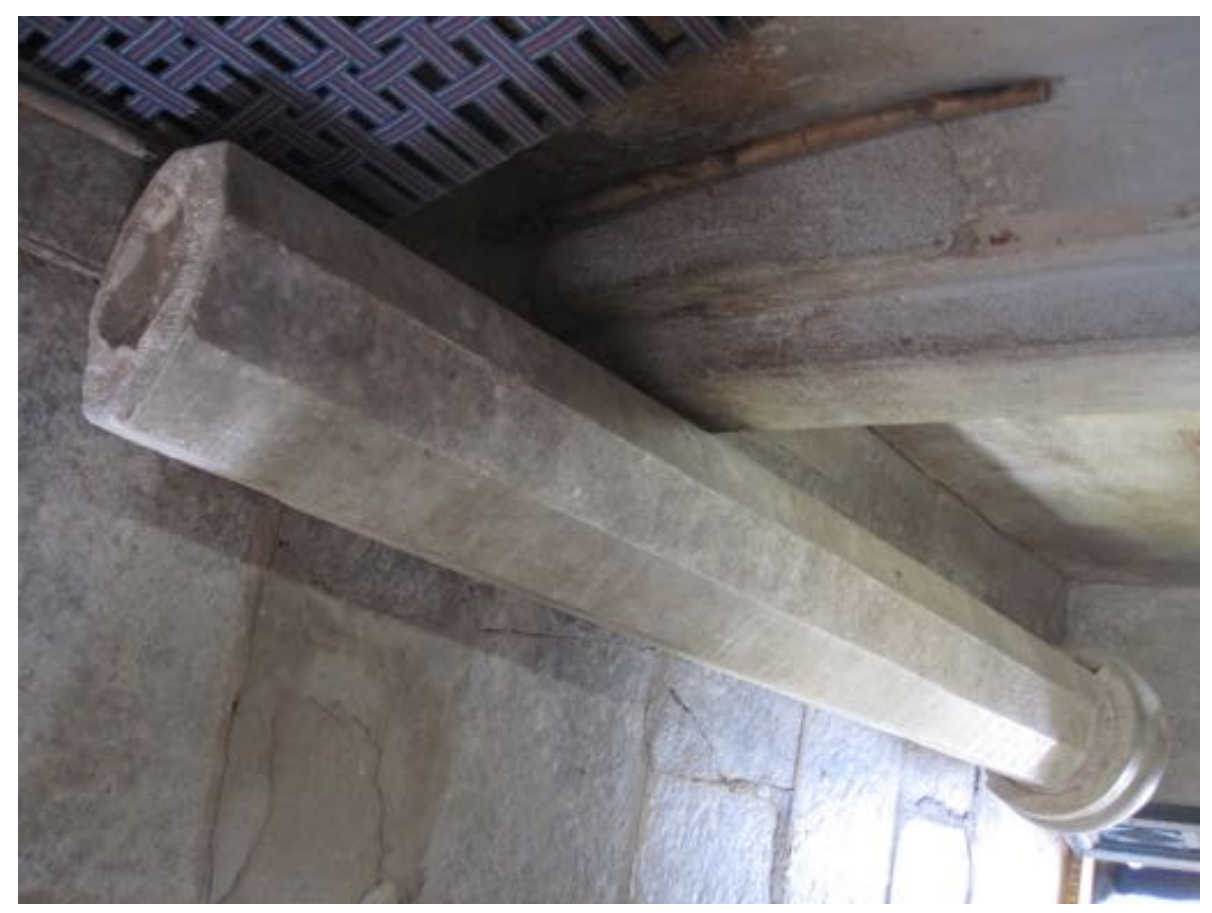


Fig. 9: Inscribed part of the octagonal pillar from Phanigiri (EIAD 104)

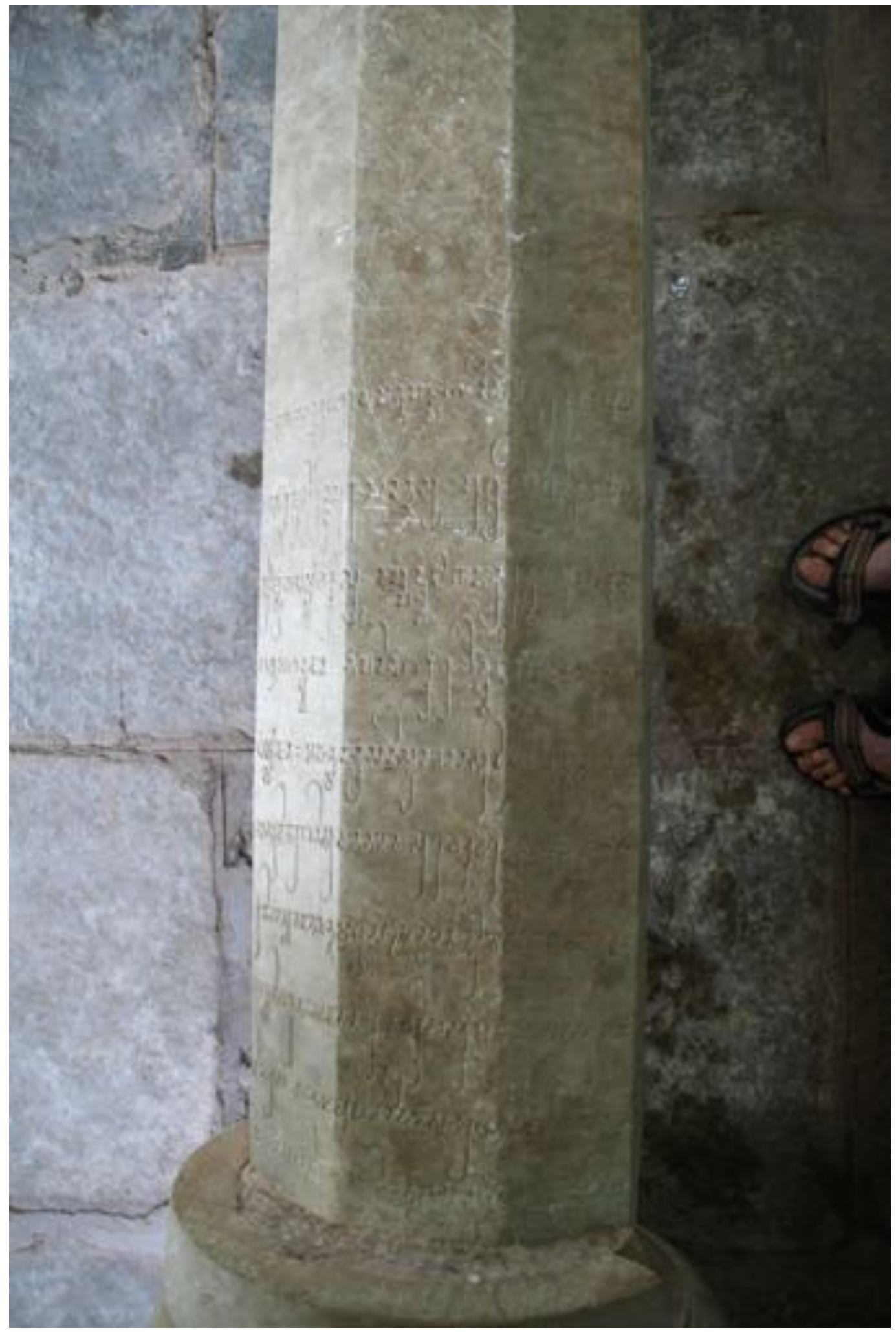


Fig. 10: Close-up of the middle portion of line 4 of EIAD 104

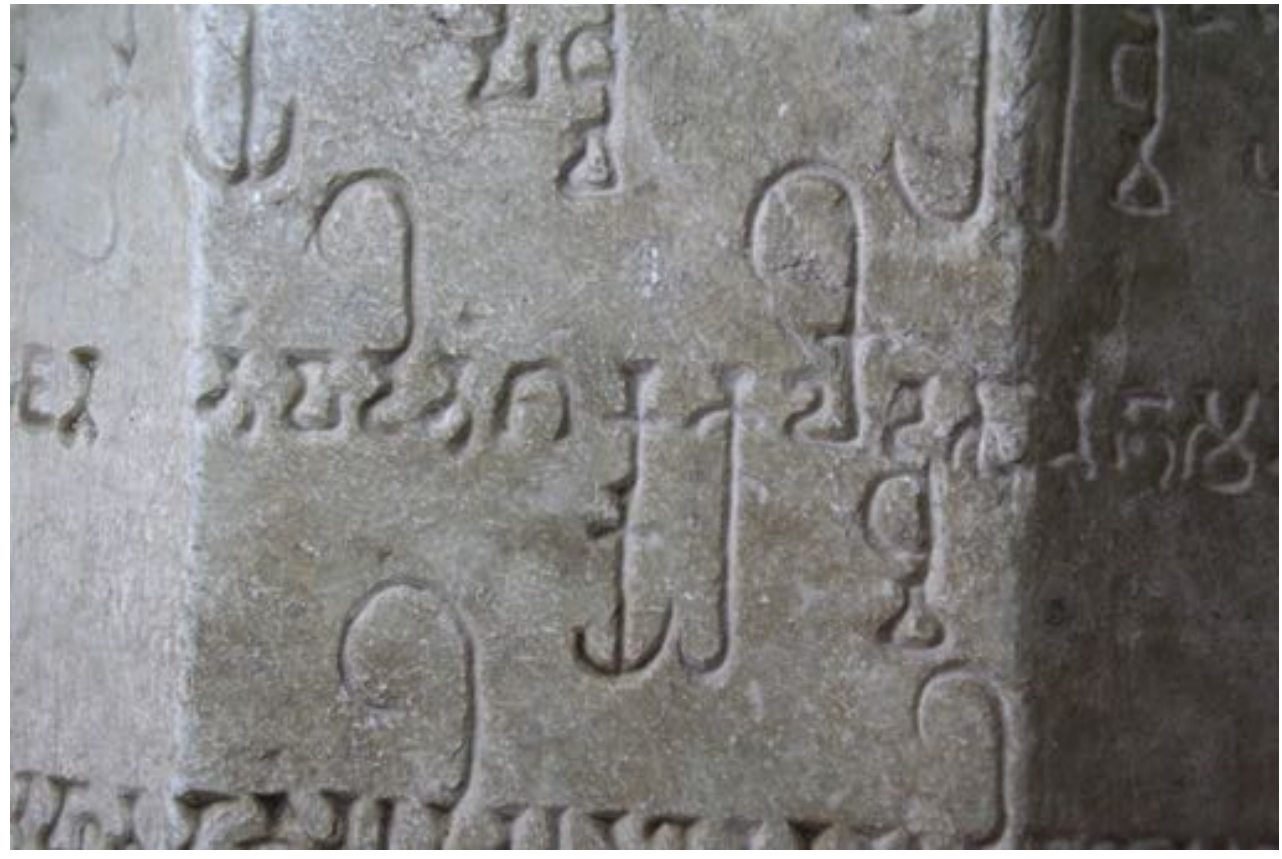

Fig. 11: Close-up of the middle portion of line 8 of EIAD 104

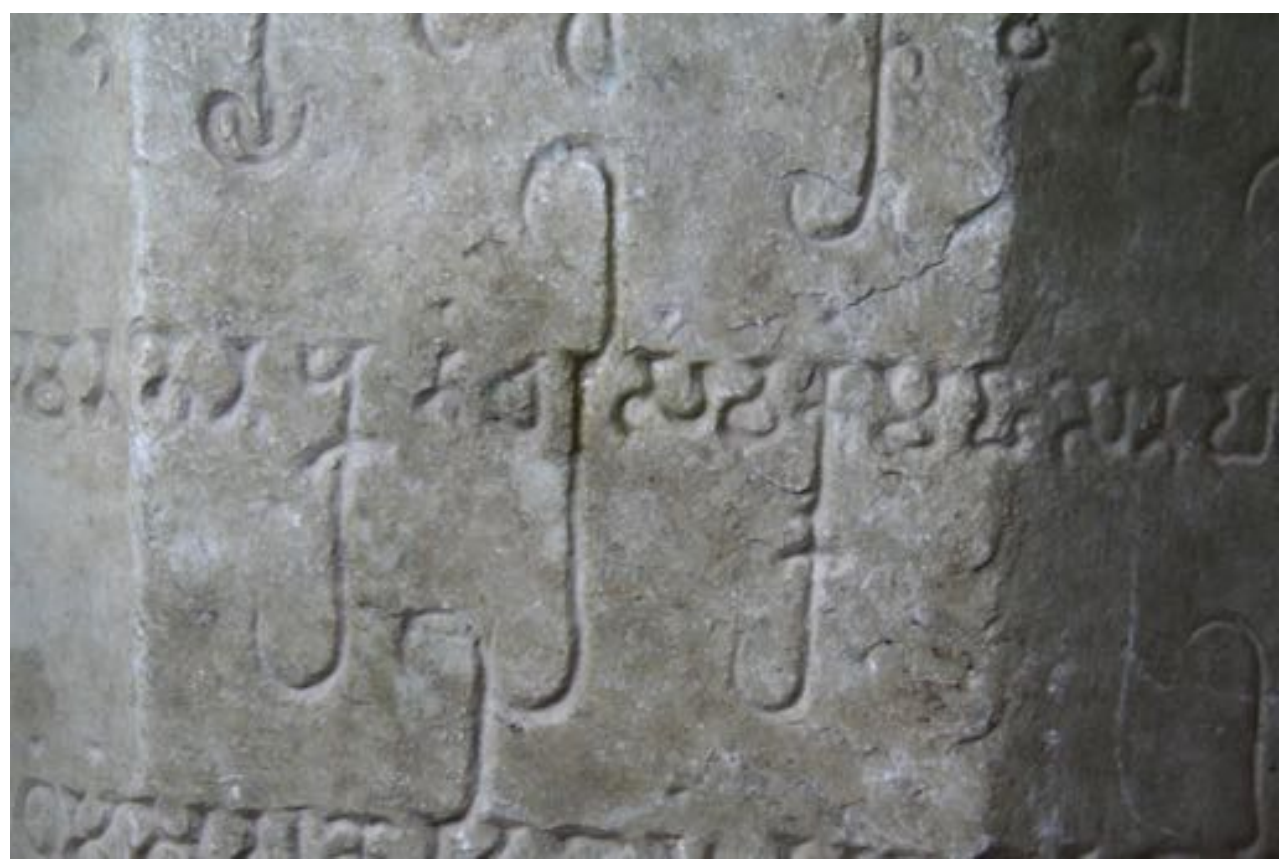


Fig. 12: Close-up of the end of line 9 of EIAD 104

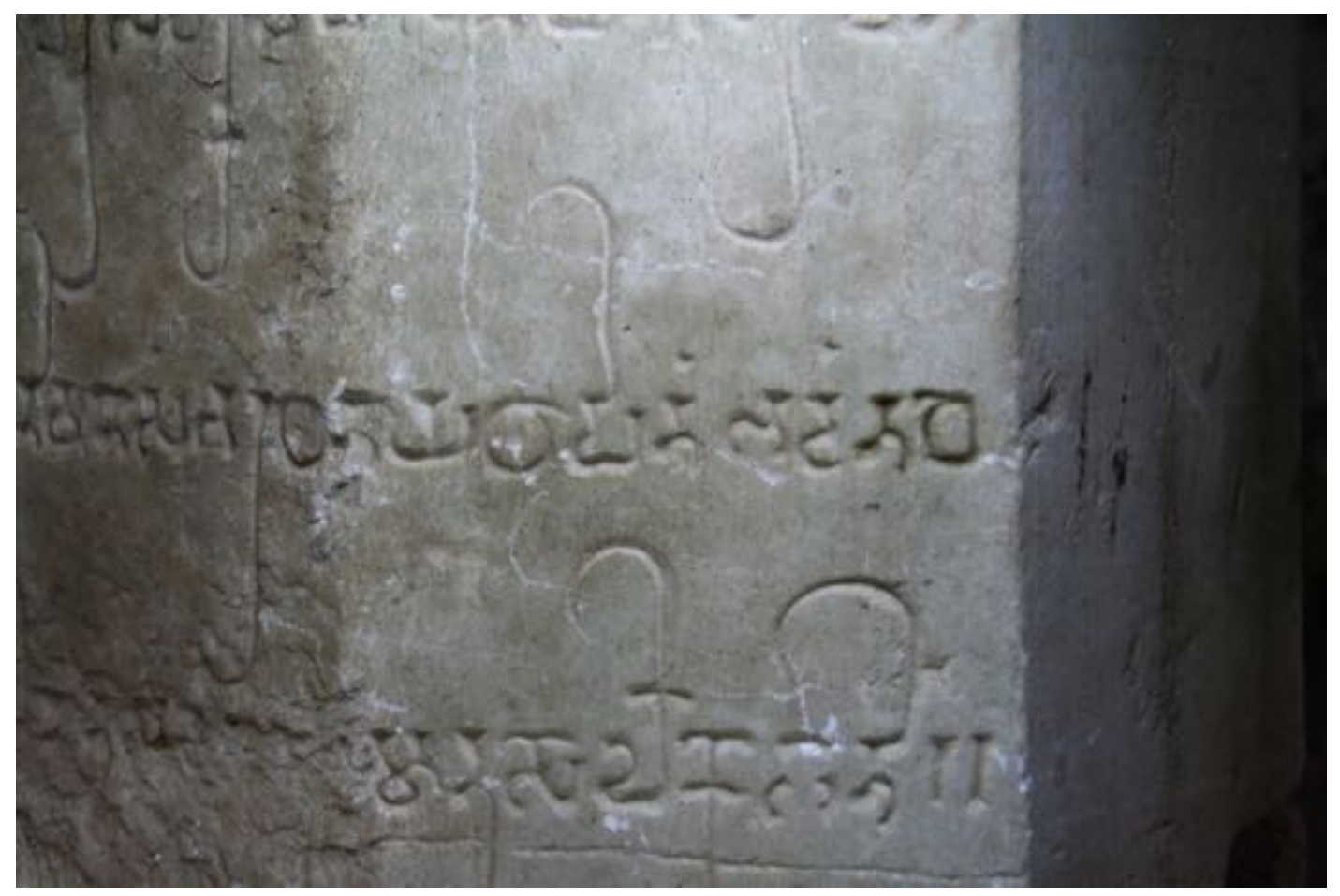

Fig. 13: Close-up of the middle portion of line 10 of EIAD 104

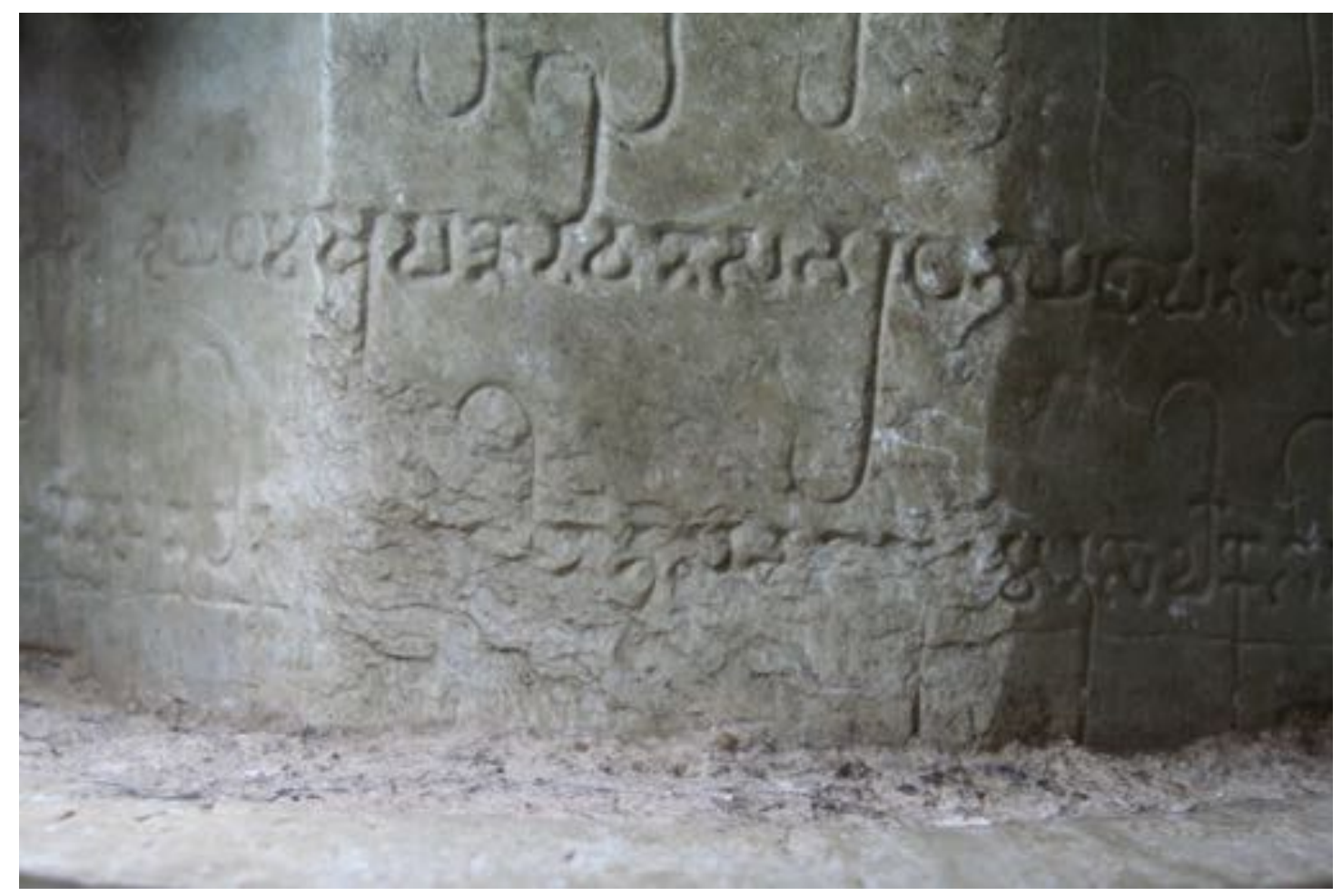


Fig. 14: Close-up of the end of line 10 of EIAD 104

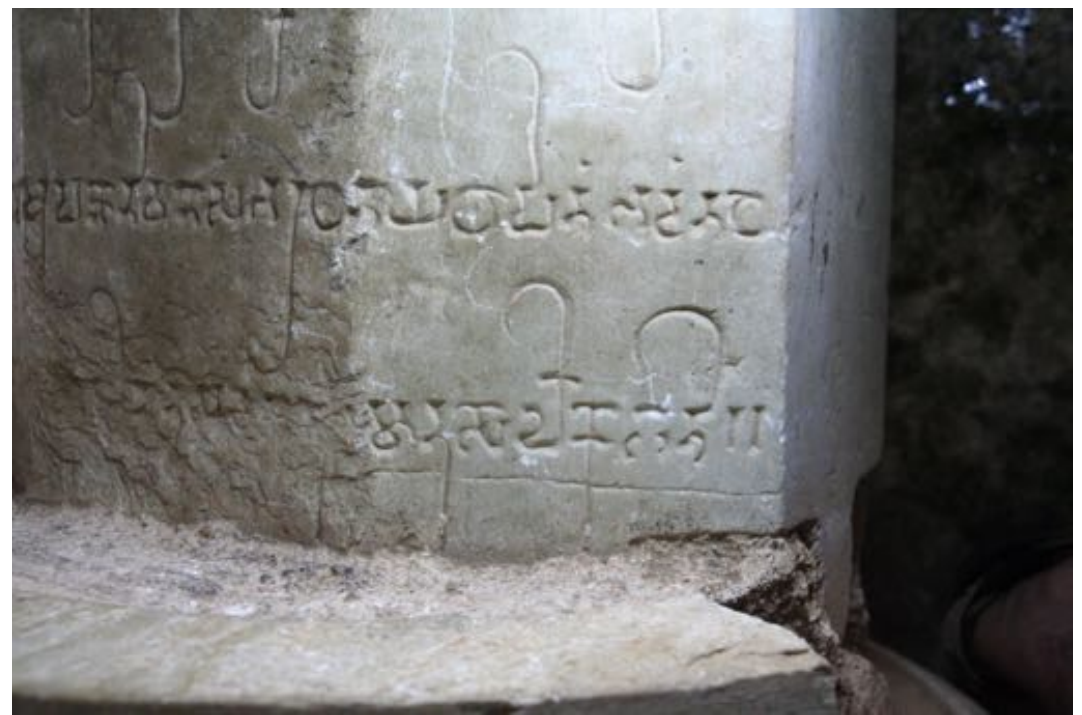

Fig. 15: Inscribed āyaka pillar from Phanigiri, after reconstruction (EIAD 114)

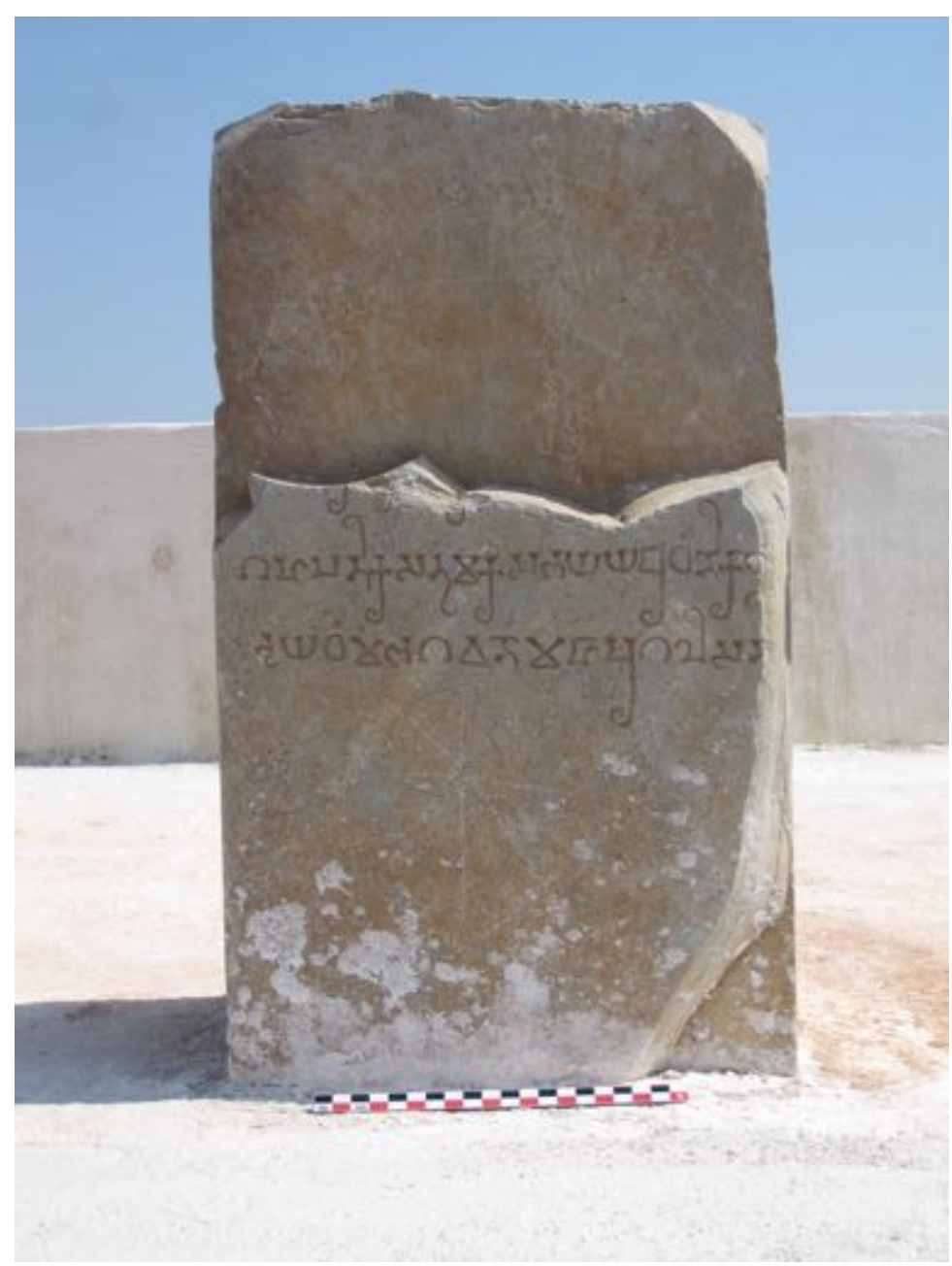


Fig. 16: Three large fragments of ayaka pillars in the main storage at Nagarjunakonda. The one closest to the wooden cases is NM 298, bearing small parts of EIAD 19

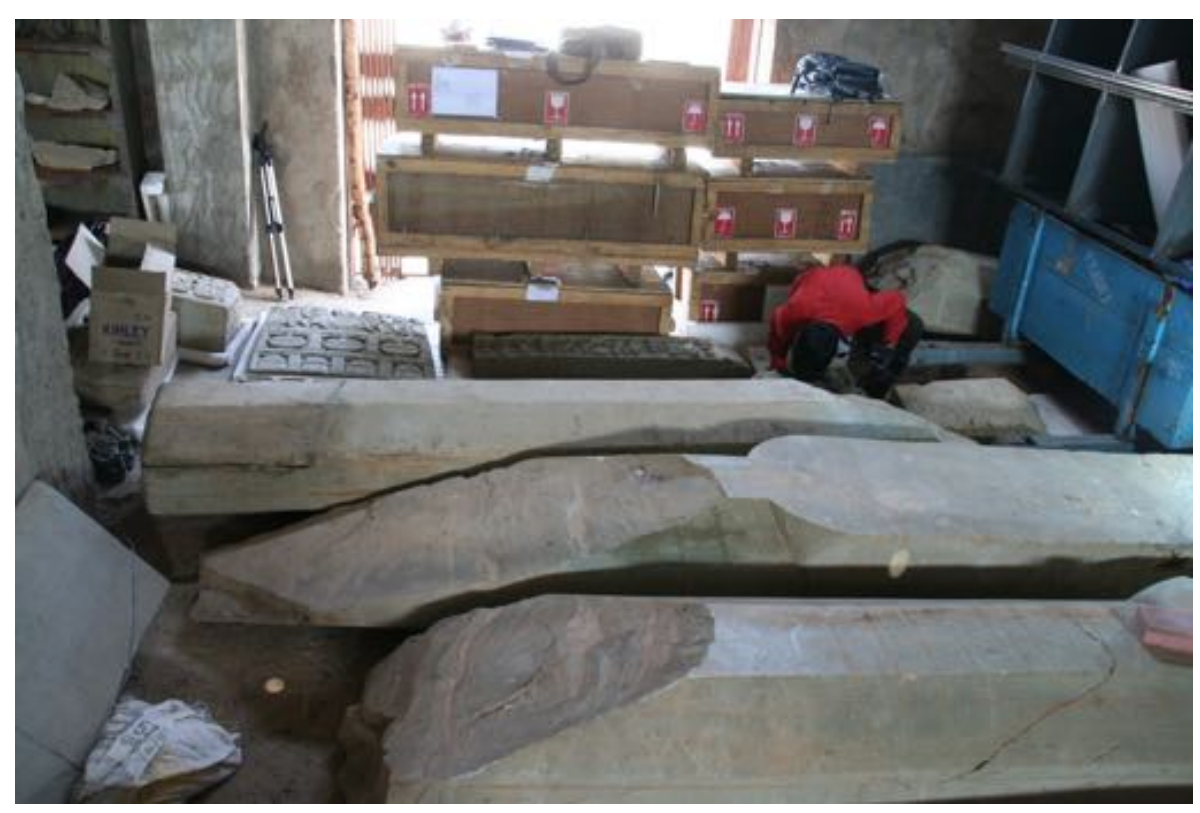

Fig. 17: Close-up of the leftmost akșaras of lines 1-3 of EIAD 104

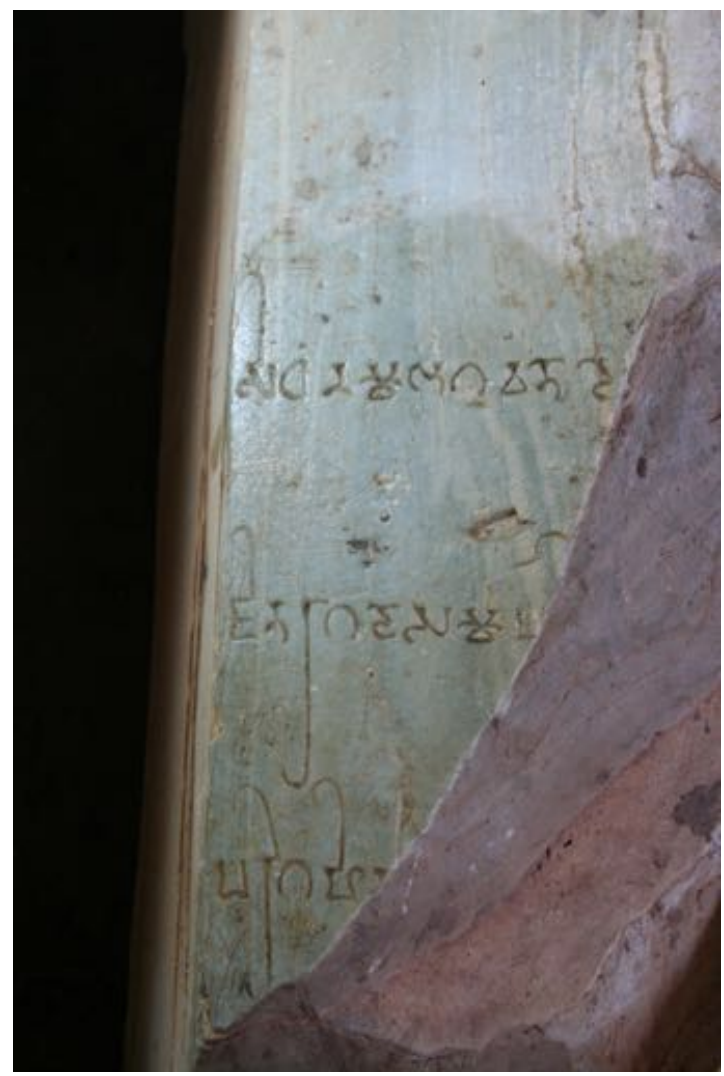


Fig. 18: Close-up of the last akșara of line 1 of EIAD 104

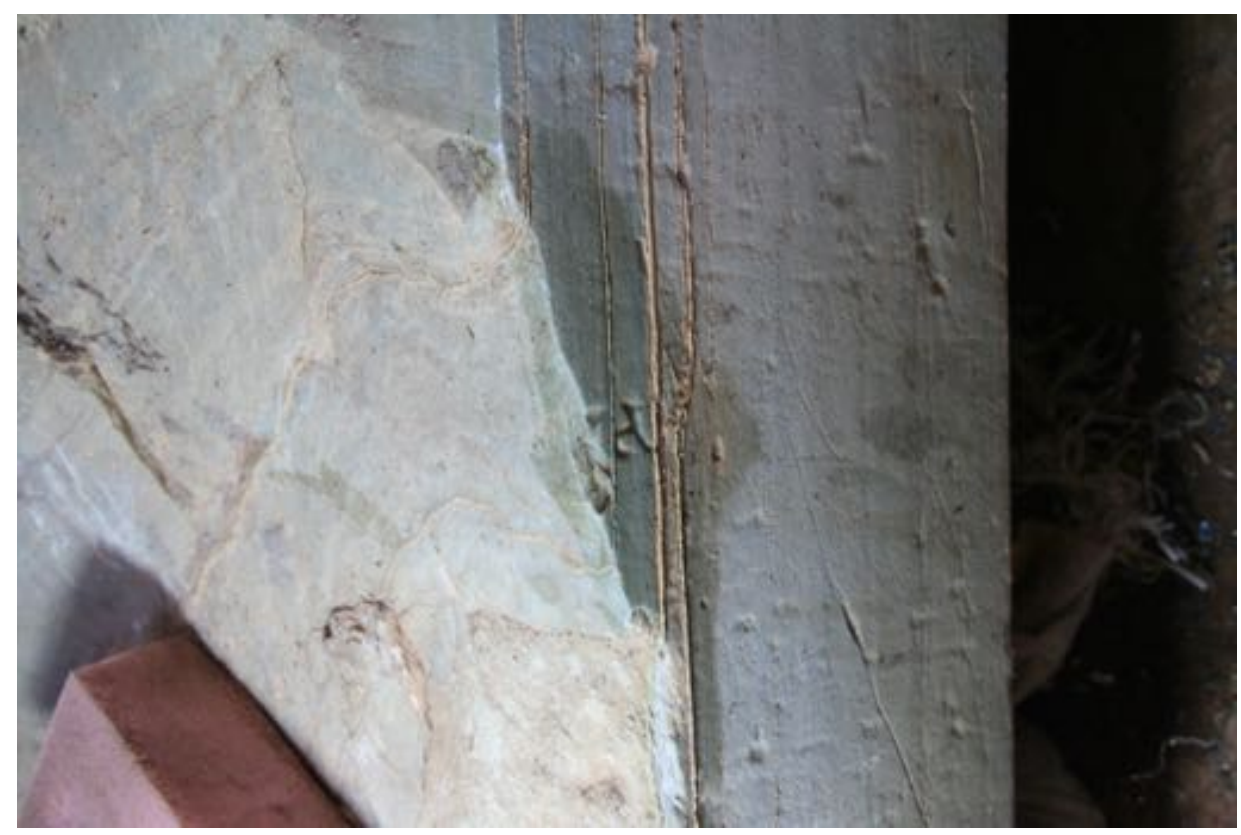

Fig. 19: Fragment NM 678 of the a ayaka pillar bearing EIAD 19

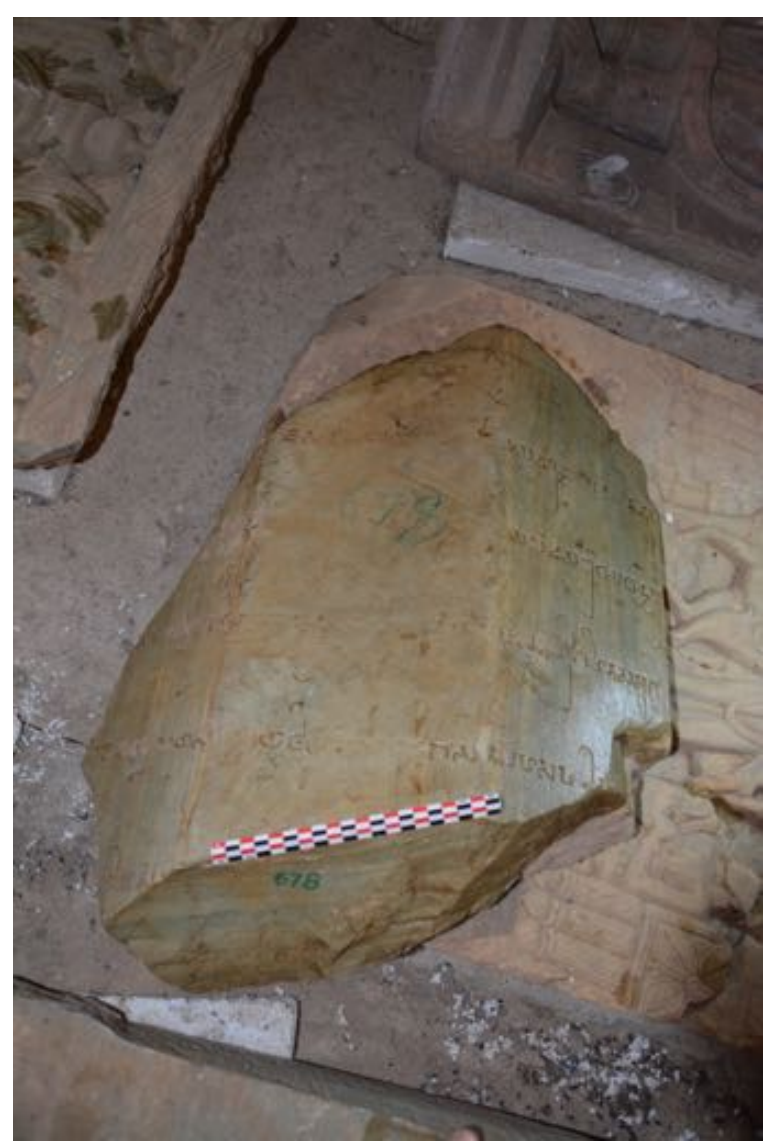


Fig. 20: Lower part of the ayaka pillar bearing EIAD 19 as preserved on the site

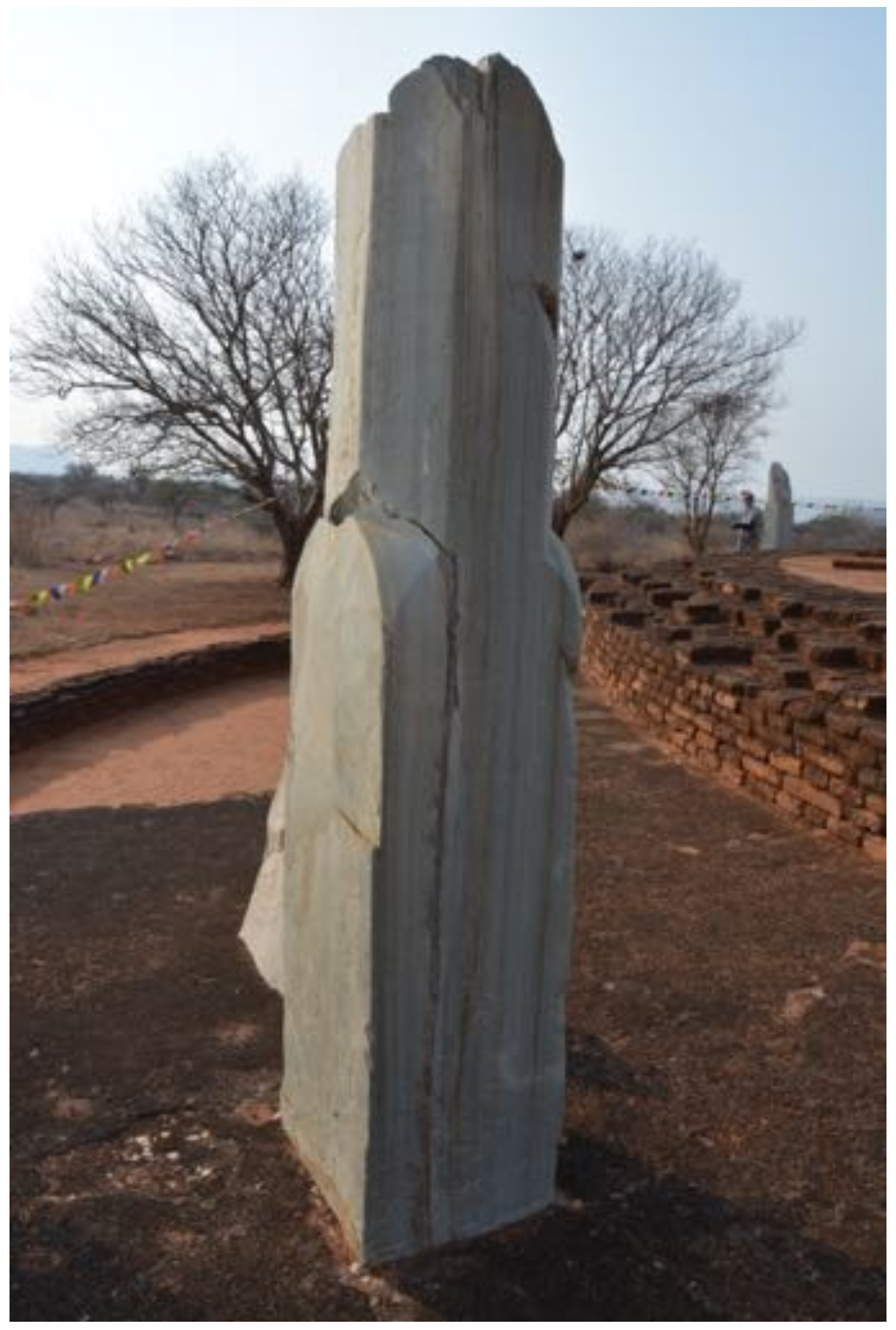


Fig. 21: Three estampage sheets for EIAD 19 preserved at Leiden assembled in one photo

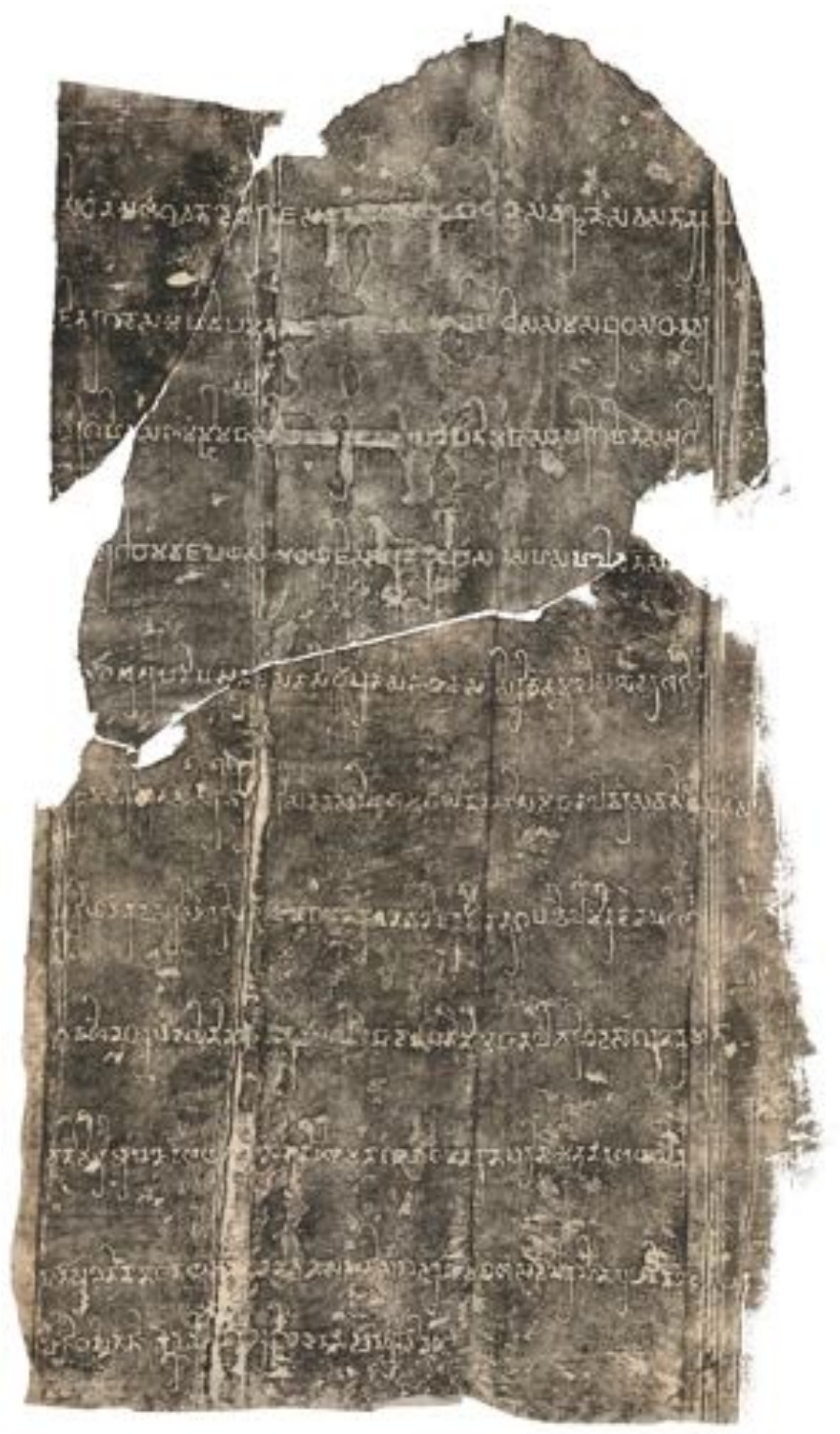

